\title{
The Avifauna of Bosque fray Jorge National Park and Chile's Norte Chico
}

\section{Douglas A. Kelt ${ }^{a}$, Hernán Cofréb, Cintia Cornelius ${ }^{c}$, Andrew Engilis, Jr. ${ }^{a}$, Julio R. Gutierrez $^{d}$, Pablo}

\section{A. Marquet ${ }^{\mathrm{e}}$, Rodrigo Medel ${ }^{\mathrm{f}}$, Peter L. Meserve ${ }^{\mathrm{g}}$, Verónica Quirici $^{\mathrm{h}}$, Horacio Samaniego ${ }^{\mathrm{i}}$, \&}

\section{Rodrigo A. Vasquez ${ }^{\mathrm{j}}$}

${ }^{a}$ Department of Wildlife, Fish, \& Conservation Biology, University of California, One Shields Avenue, Davis, California, 95616; ${ }^{b}$ Instituto de Biología, Pontificia Universidad Católica de Valparaiso, Avenida

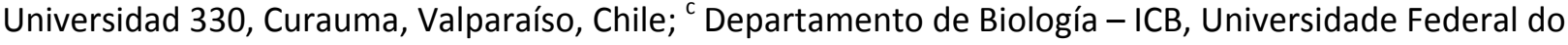
Amazonas, Av. Rodrigo Otávio Jordão Ramos 3000, 69077-000, Manaus, Amazonas, Brasil; ${ }^{\text {d }}$ Departamento de Biología, Universidad de La Serena, Av. Raul Bitran Nachary s/n, La Serena, IV Región, Chile; ${ }^{\text {e }}$ Departamento de Ecología, Pontificia Universidad Católica de Chile, Casilla 114-D Santiago, Región Metropolitana, Chile; ${ }^{\mathrm{f}}$ Departamento de Ciencias Ecológicas, Facultad de Ciencias, Universidad de Chile, Casilla 653, Santiago, Chile; ${ }^{\mathrm{g}}$ Department of Biological Sciences, Northern Illinois University, DeKalb, Illinois, 60115 - current address Department of Biological Sciences, University of Idaho, Moscow, Idaho, 83844; ${ }^{\text {h }}$ Centro de Sustentabilidad, Facultad de Ecología y Recursos Naturales, Universidad Andrés Bello, República 440, Santiago, Chile; 'Instituto de Conservación, Biodiversidad \& Territorio, Universidad Austral de Chile, Valdivia, Chile; ${ }^{j}$ Instituto de Ecología y Biodiversidad, Facultad de Ciencias, Universidad de Chile, Casilla 653, Santiago, Chile 


\section{Abstract}

The avifauna of Chile is relatively depauperate, comprising 469 extant species, of which 213 are terrestrial. However, the Coquimbo Region presents a broad ecological transition from the hyperarid Atacama Desert to the north, and the more mesic Chilean Mediterranean region of central Chile, resulting in relatively high species diversity. Approximately 130 species are found here, 8 of which are endemic to Chile although not to this region. Bosque Fray Jorge National Park is a 9,959 ha Biosphere Reserve dominated by matorral habitat and hosting up to 123 bird species. Through avian surveys and banding over nearly a decade we have documented 63 terrestrial species and discerned predictable seasonal and interannual structure to avian assemblages, at least through an extended dry period. Recent studies in the matorral habitats of the park indicate seasonal patterns that fall into 4 patterns: year-round residents, winter visitors, summer breeders, and transients. Short-term banding studies demonstrate co-occurring wintering and breeding cohorts among species of Sierra-finches (Phrygilus) in the park; such assemblages and dynamics are reminiscent of North American Mediterranean avian assemblages and pose interesting ecological comparisons. In this period of surveys there appears to have been a gradual transition of the avifauna that may be a response to anthropogenic influence and/or climate change. Research on the foraging behavior of 2 insectivorous species indicate that one of these is convergent on better-known North American taxa while the other clearly is not; these efforts suggest useful avenues for further comparative research. A remarkable coevolutionary association between the Chilean Mockingbird (Mimus thenca) and endoparasitic mistletoes (Tristerix) provides insight into potential convergent ecologies in desert regions with different evolutionary histories.

Less than $1 \%$ of the park comprises temperate forest remnants that subsist due to extensive water input from fog. Research in these remnants has emphasized the role of habitat fragmentation on avian assemblage composition and on reproductive ecology by forest-dependent species. The avifauna here comprises a subset of that found in intact Valdivian rainforest to the south, and forest remnant size 
alone explains over $90 \%$ of the variation in species numbers. One species has been particularly well studied; the Thorn-tailed Rayadito (Aphrastura spinicauda) is more abundant and has higher nestling survival in larger fragments. We summarize other work on stress responses and variation in song structure in this species. Finally, the role of birds in tree recruitment here has important implications in the face of a recent history of reduction in sizes of forest remnants; numerous birds consume the fruit of the dominant tree, olivillo (Aextoxicon punctatum), but they fail to promote successful recruitment because they defecate viable seeds in locations that provide poor survival of seedlings.

Ornithological research in Chile is undergoing a modest renaissance, and while dryland avifaunas are characterized more by what is not known and has yet to be studied than by actual ecological understanding, they provide a baseline for many exciting studies ranging from natural history to the role of migration to comparative dynamics of independent lineages in North and South America.

Key words: avian demography; foraging ecology; matorral; migration; mistletoe; remnant fog forest.

\section{Introduction}

South America is rich in avian diversity, with at least 3,340 species of birds (Remsen et al., 2014). Chile comprises $4.2 \%$ of the South American landmass but spans a latitudinal range of nearly 40 degrees (nearly 4,300 km). However, this country is biogeographically isolated by the Andes to the east, the Pacific Ocean to the west, and the hyper-arid Atacama and Sechura deserts to the north. This isolation has resulted in fewer bird species than one might expect based on its area (469 species according to Jaramillo and Barros (2013); see Fig. 1a). It has also produced a high proportion of endemic bird species (11 species $=2.3 \%$ of the terrestrial avifauna), which is about what one would expect for a South American country of its area (Fig. 1b). The northern Mediterranean and southern Atacama Desert regions - a region of major ecological transition - are relatively rich in avian diversity; the Coquimbo 
Region, with an area of $40,000 \mathrm{~km}^{2}$, supports over one-third of the species known for Chile $(S=168$ species), including 6 endemics. It also falls within the "Central Chile" endemic bird area and hosts 4 of Chile's 176 Important Bird Areas (BirdLife International, 2014), including Parque Nacional Bosque Fray Jorge (Fray Jorge hereafter) where much of our research is focused.

This region has received limited attention by ornithologists, however, perhaps reflecting the disproportionate concentration of Chile's human population in central and southern Chile, as well as more comprehensive road networks that facilitate access to study sites. Much of the limited research in this area has been conducted at Fray Jorge, located on the coast of the Coquimbo Region. As many as 122 bird species are reported to occur in or around Fray Jorge (CONAF, 1998, No date; Jaksic et al., 2004), although this includes large numbers of waterbirds and marine species. Other listings that emphasize terrestrial species indicate that about 50 species of birds occur in and around Fray Jorge, which is nearly one quarter of the 213 terrestrial species known for Chile (Vilina and Cofré, 2006). Against this backdrop it is informative that our triennial surveys within a single habitat type (matorral) in this park have yielded 63 species (Kelt et al., 2012, this contribution), which highlights 2 features of this area of Chile. First, it has remained substantially understudied by ornithologists and poorly visited by bird watchers and other avian enthusiasts, perhaps because all taxa here can also be found elsewhere in the country. We hope that this contribution will promote further observations and research on birds in the region known as "Norte Chico" (CORFO, 1950). Second, ongoing research suggests that the avifauna of this region may be in flux, with vagrants from both northern Chile and the Andes becoming increasingly common and in some cases now documented as nesting in the park. Whether these immigrants reflect gradual range expansion (e.g., a response to global climate change) or merely vagrant birds encountering equitable habitat in the face of an expanding agricultural landscape is not clear; both mechanisms merit ongoing monitoring. 
Much of Chile, but especially the northern regions, is strongly impacted by the El Niño Southern Oscillation which presents warm El Niño phases that result in higher than normal rainfall in this region, and cool La Niña phases which generally are associated with reduced precipitation here (Jaksic, 2001). Since our research at Fray Jorge began in the late 1980s we have documented several El Niño/rainy periods and predictable responses by plants and small mammals (Meserve et al., 2009; Gutiérrez et al., 2010; Previtali et al., 2010). When we initiated parallel research on birds during a dry phase, we anticipated the return of rainy periods within a few years. These rains have not arrived, and Chile currently is in a state of extreme drought (Cooke, 2015; Esposito, 2015), with reduced precipitation predicted for this region in the $21^{\text {st }}$ Century (CONAMA, 2006). Consequently, this report (and Kelt et al., 2012) is based on our understanding of avian biology in this region during a prolonged dry period. Dynamics in this region are known to exhibit ecologically important fluctuations in response to rains (Meserve et al., 2003) and we look forward to more comprehensive insights should more mesic conditions return in the coming years.

This contribution has 3 objectives. First, we summarize and update results from our 10 years of pointcount survey efforts on birds in coastal matorral habitat at Fray Jorge. Second, we summarize parallel research on avian ecology in the novel fog forest habitat found in the park. Finally, we attempt to put these observations in the context of the ecotonal nature of the Norte Chico. With the hyperarid Atacama Desert just to the north, and the more mesic Chilean Mediterranean biodiversity hotspot to the south (Myers et al., 2000), this region presents an unusually interesting fauna juxtaposed within the context of potentially sweeping climatic and environmental changes. Indeed, placed within the broader perspective of long-term research on ephemeral and perennial plants, small mammals, and predators, we believe that Fray Jorge is poised to become a global focal point for research on the impacts of climate change in ecotonal regions.

\section{Methods}




\subsection{Study site.}

Fray Jorge is located on the coast of north-central Chile, at the northern edge of the Chilean Mediterranean region, a recognized biodiversity hotspot (Mittermeier et al., 1999; Myers et al., 2000; Arroyo et al., 2006) and only ca. $200 \mathrm{~km}$ south of the hyperarid Atacama Desert (Squeo et al., 2004). The park is dominated by matorral habitat, corresponding to "matorral estepario costero" of Gajardo (1994) and both "matorral desértico mediterráneo costero" and "matorral desértico mediterráneo interior" of Luebert and Pliscoff (2006). An earlier study (Antonioletti R. et al., 1972) applied the Koeppen (1948) climatological system and treated coastal parts of this region as "Clima de estepa con nubosidad abundante (BSn; Steppe with abundant fog), and interior (but not Andean) parts of the region as either "Clima de estepa templada marginal" (BSIW; Marginal temperate steppe climate) or "Clima de estepa templada con precipitaciones invernales" (BSks; Temperate steppe climate with winter precipitation). The park provides an oasis of robust native vegetation within a region that has been severely overgrazed by domestic livestock and marginal agriculture (Bahre, 1979; Holmgren, 2002). In the Quebrada de las Vacas, where our work is based, shrub cover has remained ca. $50-55 \%$ for over half a century, and is dominated by guayacan (Porlieria chilensis), varilla brava (Adesmia bedwellii), and pucana or huañil (Proustia cuneifolia,$=P$. pungens). Coastal hills (Altos de Talinay) support remnant patches of Valdivian temperate rainforest dominated by olivillo (Aextoxicon punctatum) and petrilla (Myrceugenia correifolia), thought to be relicts of more widespread forest cover in the Tertiary and Quaternary (Villagrán et al., 2004). These remnants are the northern-most of a series of fog-supported coastal forests, fully $160 \mathrm{~km}$ north of the relict forest at Santa Inés and subject to long-term isolation and dispersal filters (Cornelius et al., 2000; Reid et al., 2002). The present and historical dynamics of tree regeneration and the functioning of these fog ecosystems is discussed in del-Val et al. (2006), Gutiérrez et al. (2008), and Barbosa et al. (2010). 
Here we emphasize research that has been pursued on the avifauna of Fray Jorge; in the discussion we expand where possible to integrate this work into the broader (albeit limited) body of information available for bird assemblages elsewhere in Norte Chico. Research at Fray Jorge comprises 2 general efforts corresponding to the principal habitats found there (matorral and fog forest). Details on methodology should be sought in the cited papers, but salient details follow here.

\subsection{Matorral.}

Cornelius et al. (2000) established 9 belt transects ( $100 \times 30 \mathrm{~m}, \geq 1000 \mathrm{~m}$ apart) with 5 point-count stations at 20-m intervals, to provide comparison with 6 fixed-radius point-count surveys conducted in remnant forests (see 2.3. Fog forest). Six of these belt transects were in lower elevation habitat (the Quebrada de las Vacas) whereas 3 were in higher-elevation matorral adjacent to remnant forests. Cornelius et al. (2000) also pursued general searches of this matorral habitat for rare or inconspicuous species. Nocturnal birds and raptors were excluded from analysis. They sampled these transects between dawn and 1300 hours for 3 consecutive days in May (autumn), August (winter), and December (spring) 1996, and in March (summer) 1997. Thereafter, these authors have maintained an annual sample each December (not included here).

Kelt et al. (2012) subsequently established 8 east-west oriented transects comprising 4 variable-circular radius point-count stations at ca. $250 \mathrm{~m}$ intervals. These have been sampled for 10 years in winter (usually August), the spring breeding season (usually November), and summer post-breeding season (February or March). Initial results (through 2010) were presented in Kelt et al. (2012); here we update trends through 2013; importantly, we exclude 3 raptors that were included in our 2012 report (Blackchested Buzzard-Eagle, Harris' Hawk, Red-backed Hawk; see Appendix 1 for scientific names of Chilean birds mentioned in text) and we added 11 species for which sufficient data have become available (Chilean Flicker, Common Miner, Creamy-rumped Miner, Dark-faced Ground-Tyrant, Oasis 
Hummingbird, West Peruvian Dove, Patagonian Tyrant, Picui Ground Dove, Rufous-banded Miner, Rufous-tailed Plantcutter, Shiny Cowbird). Analytical methods remain as presented in 2012. Briefly, we estimated population density with the program Distance 6.2 Release 1 (Thomas et al., 2010) which corrected some errors in earlier versions. We applied non-metric multidimensional scaling (NMS) and multi-response permutation procedures (MRPP) in PC-ORD 6.17 (McCune and Mefford, 2011) to test the hypothesis that avian community composition was similar across seasons. NMS uses the rank order of inter-object distances rather than the variables themselves (James and McCulloch, 1990), and the proportion of variance explained on NMS axes is not necessarily a monotonically declining function of axis rank. We used Sorensen's distance measure as this is robust to outliers and is effective with community data (Beals, 1984; McCune et al., 2002), and we applied varimax rotation to our data. NMS operates by iteratively seeking the best positions of $n$ entities (e.g., sites, time periods, etc.) in $k$ dimensions (e.g., ordination axes) such that the "stress" of this $k$-dimensional relationship is minimized (Prentice, 1977; McCune et al., 2002). Conceptually, stress is a metric that reflects departure from monotonicity in a graph of inter-sample distances in ordination space versus that in original multivariate space (for details, see McCune et al., 2002). MRPP applies a test statistic ( $T$ ) to a weighted mean withingroup distance ( $\delta$, calculated with Sørenson's distance metric), and provides an effect size $(A=1-$ $\left(\delta_{o b s} / \delta_{\text {exp }}\right)$, where $\delta_{o b s}$ is the observed value of this metric, and $\delta_{\text {exp }}$ is the mean $\delta$ calculated over all possible partitions of the data). The test statistic describes variation within groups relative to random expectation; a value of $A=1$ indicates that avian assemblage composition is identical within groups (e.g., seasons), and as the composition of groups differs the value of $A$ declines; if heterogeneity within groups equals that between groups then $A=0$ (for further detail see McCune et al., 2002). For analyses reported here we used data for 41 species over 30 seasonal sampling units (see Supplemental Table 1).

Here we also apply indicator species analysis (ISA). A good indicator species is one that occurs predictably in a given grouping (e.g., habitat or season; Dufrêne and Legendre, 1997); in our case this 
refers to species that are found in only one season at our study site. ISA determines the indicator value of a species as $I V_{k j}=100\left(R A_{k j} * R F_{k j}\right)$ where $R A_{k j}$ and $R F_{k j}$ are the relative abundance and relative frequency of species $i$ in group $j$ (e.g., season; for analytic details see McCune et al., 2002). The significance of $\mathrm{IV}_{\mathrm{kj}}$ is calculated with a Monte Carlo approach in which sample units are randomly reassigned and IV re-calculated; the proportion of such randomized IV values that are as large or larger than the observed IV value is the probability of such an observed value occurring by chance. We ran 1000 such iterations in PC-ORD (McCune and Mefford, 2011).

In a related effort, we established a MAPS (Monitoring Avian Productivity and Survival) mist netting program in October 2008 following methods established by DeSante and Kaschube (2007). Six MAPS stations were established and monitored between 15 October and 20 December 2008, and again in 1020 September 2013. We captured over 1,350 individuals, banded over 1,000, and obtained over 1,000 images of hand-held birds in part to document criteria for molt and age/sex determination, leading to a manual to the plumages of birds in this region (Pyle et al., 2015a, b). In addition, however these efforts allowed us to document previously unknown patterns of assemblage composition and molting strategies of birds in the park (molting strategies outlined in Pyle et al., 2015a, b). Only preliminary results are available at this time, but we provide these to complement data available from point-count surveys.

Engilis and Kelt $(2009,2011)$ assessed foraging ecology of 2 common species in matorral habitat at Fray Jorge, the Tufted Tit-Tyrant and the Plain-mantled Tit-Spinetail. These papers were based on extensive tracking of individual foraging birds and recording observations for as long as they could be followed without disturbance. Duration of behaviors were recorded using a stopwatch and behaviors were characterized using categories outlined by Fitzpatrick (1980). We noted substrate used, number of individuals in groups, whether mixed-species flocks were present, and we characterized foraging activity with basic statistics (mean, SD) and linear regression (e.g., foraging activity vs. shrub cover). 
In the mid-1990s, Martínez del Rio and colleagues $(1995 ; 1996)$ documented a mutualistic relationship between 2 species of columnar cacti, an endophytic mistletoe (Tristerix aphyllus), and the Chilean Mockingbird. This system was subsequently studied extensively by Medel and colleagues (Medel et al., 1995, 2002, 2004, 2010; Botto-Mahan et al., 2000; Medel, 2000, 2001). The resulting body of work has employed diverse approaches and both field and laboratory analyses. We summarize salient features of this in the results, much of which has been conducted in protected areas in the Coquimbo Region, most notably Fray Jorge and the Reserva Nacional Las Chinchillas, and we direct readers to the original papers for details on methodology.

\subsection{Fog forest.}

In parallel to their work in matorral habitat, Cornelius et al. (2000) sampled avian communities in 6 remnant fog forests in the Altos de Talinay. These remnants range in size from 0.5 to 22.5 ha, and were sampled with fixed-radius $(25-\mathrm{m})$ point count stations separated by at least $100 \mathrm{~m}$. Observations lasted 8 minutes at each station, with uneven sampling effort across remnants reflecting different spatial extents. Note that tapaculos (Rhinocryptidae) were recorded only if observed within the sampling radius; these birds have loud calls that frequently can be heard at great distance. Vergara and Marquet (2007) studied seasonal variation in the influence of landscape features on the reproductive ecology of the Thorn-tailed Rayadito, a common and visible bird characteristic of temperate rainforest in Chile and found in rainforest remnants at Fray Jorge. They established 52 nest boxes in 28 forest remnants ranging from 0.03 to 30 ha, and visited these weekly from late September through late December 2005 to assess reproductive success, nest/brood fate, and signs of nest predation. In 2007 these nest boxes were transferred to R. Vasquez, who converted them to a design used elsewhere in Chile (Moreno et al., 2005), allowing comparisons between different populations in Chile, and increased the number of nest boxes to 100 . Vasquez and his collaborators employed these nest boxes primarily in their studies on spatial variation in song and physiological responses to stress among Thorn-tailed Rayaditos from Fray 
Jorge and populations in temperate Chile. Readers should consult papers cited below for methodological details.

Finally, in response to evidence that the fog forests at Fray Jorge are receding at their leeward edges (del-Val et al., 2006; Stanton et al., 2014), recent research has focused on the role of birds in fruit and seed dispersal, and more broadly on recruitment, by the dominant tree species in these remnants, olivillo (Nunez-Avila et al., 2013). These authors mapped individual trees and assessed source limitation (individual fecundity), dissemination limitation (focal tree observation and seed traps), and establishment limitation (experimental seed additions) to evaluate which step might be hindering recruitment.

\section{Results and Synthesis}

\subsection{Matorral.}

Cornelius et al. (2000) reported 30 species from matorral habitat, and their analyses suggest that the higher-elevation transects (adjacent to fog forest remnants) differed modestly to significantly from those in the Quebrada de las Vacas, presumably reflecting inclusion of forest species. Because the focus of these authors was on forest-dwelling birds we integrate their results from matorral habitat with those of Kelt et al. (2012) which focused solely on the latter habitat. These combined efforts have documented 67 terrestrial species in this habitat (see Appendix 1), 41 of which are included in quantitative assessments.

Using 10 years of point-count data (Feb. 2004 through Feb. 2014), the best NMS ordination included 3 dimensions (Fig. 2). Stress was significantly lower than expected with randomized data (stress $=7.05 ; P$ $=0.001$ ), and the resulting axes explained $40.2 \%, 6.6 \%$, and $48.6 \%$ of the variance in the ordination (total $=95.4 \%$ ). Avian assemblages differed across all 3 seasons (MRPP: Winter vs. Summer, $T=-8.12, A=$ $0.15, P<0.0001$; Winter vs. Breeding, $T=-5.71, A=0.10, P=0.0004 ;$ Summer vs. Breeding, $T=-2.25, A=$ 
$0.03, P<0.04$ ). However, visualization of these results (Fig. 2) suggests that summer and the breeding season differ only in the anomalous placement of Session 8 (October 2006). In this session we documented unusually high concentrations (more than 2 SD above the seasonal mean) of Band-tailed Sierra-Finch and Mourning Sierra-Finch, as well as modest numbers of the generally rare (in this season) Rufous-tailed Plantcutter and West Peruvian Dove. Band-tailed Sierra-Finches generally are most common during the breeding season, but were unusually abundant in this session. In contrast, Mourning Sierra-Finches are common in the breeding season (but much more so in winter), yet they were extraordinarily common in the 2006 breeding season. As noted, the other 2 species typically are uncommon in either the breeding season (West Peruvian Dove) or in winter and breeding seasons (Plantcutter), but both were unusually abundant in the 2006 breeding season. When Session 8 is removed from analyses, the separation between summer and breeding assemblages becomes nonsignificant (MRPP: $T=-1.77, A=0.03, P=0.062$ ), whereas that between other seasons remain significant; this reflects seasonal patterns reported by Kelt et al. (2012). The only other outlier appears to be Session 29; this session was marked by extraordinarily high numbers of observations of California Quail, as well as high numbers of Chilean Swallow and the generally uncommon (in this season) Grayhooded Sierra-Finch and Great Shrike-Tyrant. Removal of Session 29, however, has no qualitative impact on the results.

In our earlier report on this avifauna (Kelt et al., 2012) we noted that the breeding season of 2007, rather than that of 2006, was anomalous (e.g., Session 11 rather than Session 8). We explained our earlier results on the basis of 2007 having been an exceedingly dry year ( $48 \mathrm{~mm}$ rainfall), such that the spring breeding season was climatically reminiscent of summer conditions and therefore had a summer avifauna without breeders. Indeed, we noted that 2006 was an unusually wet year $(147 \mathrm{~mm})$. The differences in results (Kelt et al., 2012 vs. results reported here) appear to reflect differences in the set 
of bird species analyzed, and in part is a product of our more comprehensive database, but this also underscores the sensitivity of ordinations to relatively small changes in input data.

Given this constraint, however, our data suggest two key trends in the structure of Fray Jorge avifaunas. The first is that these faunas vary seasonally but return to similar structure each year; that is, there is a predictable avifauna in winter, the spring breeding season, and in the summer post-breeding season. However, these data also indicate an interesting temporal shift in faunal composition over time in ordination space. It is clear that a general and gradual change in species composition has occurred during the period of study, with a gradual shift from the bottom-left to the top-right in ordination space (Fig. 2). This appears to reflect the increasing presence of species otherwise known from the Andes or from further north in Chile, such as the Creamy-rumped Miner and the Oasis Hummingbird (Fig. 3). The former generally is "rare to locally uncommon ... at high elevations" of central Chile and Argentina (Ridgely and Tudor, 1994:29; see also Jaramillo et al. 2003:156) but has been observed at our site in winter of 2012 and 2013. Even more surprising, the latter species was thought to range in Chile south to the middle of Atacama Region (perhaps 300 km N Fray Jorge), but has been observed in Fray Jorge since late 2011 and now breeds there. These changes appear to reflect real changes in the local avifauna, most of which would go unnoticed in the absence of a standardized and long-term sampling regime.

Indicator species analysis (Table 1 ) highlighted 16 species with significant IV values $(P<0.05)$ and another 4 that presented strong trends $(P<0.10)$. Species highly associated with summer season were the House Wren, Chilean Swallow, and Dusky-tailed Canastero; Chilean Flicker exhibited a strong trend. Winter assemblages were strongly influenced by (i.e., consistently included) the Scale-throated Earthcreeper, Green-backed Firecrown, Mourning Sierra-Finch, Common Miner, Chilean Tinamou (all $P<$ 0.01), Gray-hooded Sierra-Finch, and Patagonian Tyrant. The Austral Thrush exhibited a strong trend. Finally, the Dusky Tapaculo, Black-chinned Siskin, Grassland Yellow-Finch, Band-tailed Sierra-Finch, Chilean Pigeon, and White-crested Elaenia all are strong indicators of the breeding season, and the Page | 13 
Eared Dove and Giant Hummingbird both exhibited strong trends. Note that some of these species are year-round residents (e.g., Chilean Swallow, House Wren, Dusky-tailed Canastero, Chilean Tinamou, Dusky Tapaculo, Eared Dove, Chilean Pigeon), so their indicator status reflects seasonal patterns in detectability rather than in presence (e.g., noise rather than signal). Others, however, reflect the natural history of these species in north-central Chile. For example, several species are highly migratory (e.g., Giant Hummingbird, Sierra-finches, White-crested Elaenia).

Finally, and possibly related to these documented changes in avifaunal structure, preliminary monitoring with a MAPS approach has documented temporal overlap between wintering and breeding cohorts of Mourning and Gray-hooded sierra-finches, and Rufous-collared Sparrow (Zonotrichia capensis). Such integrative bird assemblages also occur in some North American Mediterranean systems (Pyle, 1997) and provide a foundation for further comparative research. Nothing is known, for example, of the influence of rainfall or temperatures on the rigidity of seasonal movements. With climate change predicted to reduce annual rainfall in this part of Chile (CONAMA, 2006), further study on factors influencing seasonal patterns among bird species here would be enlightening.

\subsubsection{Foraging ecology of insectivorous birds.}

Both Plain-mantled Tit-Spinetail and Tufted Tit-Tyrants are insectivorous, and whereas the former is a perch-gleaning specialist (Engilis and Kelt, 2011), the latter is more generalist and employs hovergleaning and flycatching in addition to perch-gleaning (Engilis and Kelt, 2009). Both species favored areas with denser shrub cover, particularly the common shrubs guayacán, romerillo (Baccharis linearis), and in the case of Tufted Tit-Tyrants, varilla brava (Engilis and Kelt, 2009, 2011). Plain-mantled TitSpinetails enter mixed-species foraging flocks and appear convergent on North American aegithalids, whereas Tufted Tit-Tyrants forage singly or in pairs, appear to defend foraging territories, and are clearly 
not convergent on Holarctic parids or regulids (contra Meyer de Schauensee, 1966; Jaramillo et al., 2003).

Work to date has targeted only 2 relatively inconspicuous species, and not surprisingly serves primarily to raise further questions on seasonality and the influence of climatic extremes (drought, ENSOassociated rainy periods), extent of ecological convergence (and where present, convergence on what other group), and the impact of these species on arthropod communities in matorral shrublands. If climate change reduces rainfall and increases evapotranspiration in this region (CONAMA, 2006) then soil moisture is likely to decrease (Bartholomeus et al., 2011; Silvertown et al., 2015). These two bird species preferentially foraged in shrubs that were able to access water sources year-round; the impact of climate change on plant productivity via reduced soil moisture is one potentiality that could have a substantial impact on avian foraging and hence on avian assemblage structure. Especially given the climatic and structural parallels between Chile and semi-arid regions in other Mediterranean climates, these results should be viewed as a starting point for additional work on other species.

\subsubsection{Chilean Mockingbird-Cactus-Mistletoe symbiosis.}

The mistletoe genus Tristerix includes 11 species distributed from subpáramo elevations in Colombia to lower elevations in and near the Andes of Chile and Argentina. Most Tristerix have broad host ranges, but $T$. aphyllus is a specialized mistletoe that, unlike its congeneric species, lacks leaves and parasitizes only columnar cacti. In north-central Chile a unique tripartite mutualism has been documented, in which the Chilean Mockingbird is the sole disperser of seeds for T. aphyllus. In Fray Jorge and elsewhere in the ecotonal region of the Norte Chico, the mistletoe parasitizes columnar cacti (Echinopsis and Eulychnia --Amico et al., 2007). Originally reported by Martínez del Rio et al. (1995; 1996), this system has proven to be a productive system for further work from avian, botanical, and evolutionary ecological perspectives. Chilean Mockingbirds swallow whole mistletoe fruits, passing the mucilaginous seeds in feces (for a 
summary, see Guerrero et al., 2012). Spine length varies across individual cacti, and Chilean Mockingbirds tend to deposit feces on cacti with short spines or on cacti that have previously been visited, leading to an aggregated distribution of mistletoe (Martínez del Rio et al., 1995; Medel et al., 2004). Seeds produce a long radicle (apparently the largest of the family) that grows up to 8 weeks or until contact with cactus epidermis; mistletoe infection has fitness costs for the cacti (Silva and Martínez del Rio, 1996) and cacti with longer spines provide a defense against mistletoe infection as the distance the radicle must grow to contact the cactus cuticle is greater. In addition, Medel and colleagues (Medel, 2000; Medel et al., 2010) have shown that cacti and mistletoe are in an arms race that selects for longer spines as they prevent birds from perching on the top of the cactus columns hence avoiding infection. Unlike some other mistletoe frugivores, however (Watson and Rawsthorne, 2013), Chilean Mockingbirds have a relatively catholic diet and their range extends well beyond that of Tristeryx; thus, as is the case with the mistletoe Struthanthus flexicaulis and Plain-crested Elaenia in Brazil (Guerra and Pizo, 2014), the mutualism between Tristerix and Chilean Mockingbirds in northern Chile is highly asymmetric.

\subsection{Fog forest.}

Cornelius et al. (2000) reported 21 species in the fog forests of Fray Jorge, and showed that these were compositionally more closely related to avifaunas of remnant temperate rainforests from central (Palmas de Ocoa National Park, ca. 250 km S Fray Jorge) and southern Chile than to the adjacent matorral habitat. They also documented this avifauna to be a subset of assemblages found in intact temperate rainforest of southern Chile, and that remnant area alone explained up to $91 \%$ of the variation in species number. The species-area relationship was more characteristic of oceanic archipelagos than mainland habitat patches, which the authors attributed to limited "rescue effects" (Brown and Kodric-Brown, 1977), in turn reflecting the great distance to any source populations. Finally, Cornelius et al. (2000) reported a strongly nested structure of avifaunas across remnant patches, suggesting that smaller fragments are less likely to protect species against stochastic extirpation. 
Reflecting patterns at the faunal level, Thorn-tailed Rayaditos were more abundant in larger and more connected remnants, and patch attributes were more important than habitat structure (Vergara and Marquet, 2007). Similarly, nestling survival was greater in larger remnants, lower in more connected remnants, and habitat structure was less important than these patch attributes.

Quirici et al. (2014b) evaluated stress responses in Thorn-tailed Rayaditos across a latitudinal gradient from Fray Jorge to Isla Navarino (in the subantarctic Magallanic Region). They found that northern populations (Fray Jorge) overall experienced greater stress (as reflected in circulating levels of glucocorticoids), supporting the hypothesis that stress is responding primarily to environmental instability. Further, the fact that individual birds did not vary in their stress response across the latitudinal gradient over 3 years of study suggests that resource availability compensated for environmental stressors. In addition, these levels of stress are reflected in telomere length, the ending cap of chromosomes, which are correlated with fitness (e.g., shorter telomere length, lower survival). Quirici et al. (2014a) compared levels of glucocorticoids and telomere length of nestlings of the same age in Fray Jorge and Navarino Island $\left(55^{\circ} \mathrm{S}\right)$. They found that levels of glucocorticoids of nestlings (12 days old) were higher in Fray Jorge and that telomere length was shorter in this population. Current research is evaluating survival probability of nestlings in these 2 contrasting populations.

Ippi et al. (2011) studied variation in songs of the Thorn-tailed Rayadito across $22^{\circ}$ latitude (from Navarino Island in extreme southern Chile to Cerro Sta. Ines located ca. $150 \mathrm{~km}$ S Fray Jorge). Only one of 4 song types exhibited geographic variation, which the authors attributed to variation in habitat structure (temperate rainforest vs. subantarctic or sclerophylous forest). Additionally, Moreno et al. (2005; 2007) and Quilodran et al. $(2012 ; 2014)$ documented nesting behavior in Thorn-tailed Rayaditos, and Ippi et al. (2013) evaluated antipredator behavior, although their study did not include any sites in the Coquimbo Region of Chile. 
Other work in Fray Jorge fog forests has emphasized the role of birds in the recruitment of a temperate rainforest species that occurs here at the northern edge of its range. Olivillo is a dominant element of the forests at Fray Jorge. This species is dioecious, and Nuñez-Ávila et al. (2013) evaluated fruit production, dispersal, and seedling establishment across replicate large and small forest fragments. Olivillo suffers recruitment limitation at all stages (source, dispersal, and establishment), and although 7 species of birds consumed fruits from this species, all were predominantly species of nearby matorral habitat; although they dispersed seeds (via feces) between forest patches, they tended to deposit these in poor sites for generation (fragment edges, beneath canopies where density-dependent mortality is likely to be greater). Independent work by these authors (unpublished) has documented significant gene flow through this environment, suggesting a need for work on male reproductive success to understand this species' reproductive ecology; this species is thought to be pollinated by insects (Aizen and Ezcurra, 1998) so the role of birds in the pollination ecology of this species likely is minimal.

\section{Summary - Where do we go from here?}

Chile's Coquimbo Region (and, to a lesser extent, the Atacama Region just to the north) was effectively established as a transitional region between the hyperarid "Norte Grande" and the more moderate Mediterranean region of central Chile (CORFO, 1950). It may not be surprising that birdwatchers as well as ornithologists within Chile allocate their efforts to southern and extreme northern Chile, and the Andes, and that intervening zones such as Coquimbo Region remain relatively poorly studied. Ecologists appear to have been similarly influenced by the distribution of known avian diversity in Chile. Indeed, the only terrestrial sites that have been well-studied in Norte Chico are the Reserva Nacional Las Chinchillas (e.g., Jaksic and Lazo, 1999) and Fray Jorge (summarized herein). In the face of global climate change and the potential for southern expansion of the Atacama Desert (which reaches its southern extent near the border between the Atacama and Coquimbo regions), this region is well poised to 
provide important insights to biotic responses to these extrinsic abiotic drivers. By way of providing suggestions for future work on birds in this region, we separate 2 interrelated themes.

\subsection{Ecology and natural history.}

It is no understatement to emphasize that most species remain utterly unstudied in this region. This includes 3 species of tapaculo (Passeriformes, Rhinocryptidae) for which extensive research in central and southern Chile (Willson et al., 1994, 1995, 2014; De Santo et al., 2002; Cofré et al., 2007) provides compelling bases for the development of testable hypotheses. Although plants and mammals have been thoroughly studied here (see other contributions in this Special Issue), even a basic understanding of avian responses to extrinsic factors such as El Niño events remains anecdotal in most cases. With the recent completion of the first manual to avian plumages for any region of temperate South America (Pyle et al., 2015a, b) the stage also is set for the application of comprehensive monitoring of avian productivity and survival (e.g., a MAPS approach --- DeSante and Kaschube, 2007), with critical implications for conservation in this biodiversity hotspot. We know that some small mammals indirectly facilitate establishment by both native and invasive plant species (del-Val et al., 2007; Madrigal et al., 2011), but no research has addressed the ecological role of any ground foraging species in this system, leaving unclear the role of such scratch foraging in terms of germination or survival of seedlings.

\subsection{Seasonality and migration patterns.}

We commented briefly on seasonal patterns in Fray Jorge (see also Kelt et al., 2012), but much remains poorly understood. How critical is Fray Jorge as a stop-over point for migrating species, which species employ Fray Jorge as a stop-over as part of a longer journey, and for which is it the end point of a shortor long-distance migration? Jahn et al. (2004) noted that testing hypotheses about migration in South America is not possible "because so little is known about the extent of migration on any scale within South America" (emphasis theirs), and Faaborg et al. (2010:29) noted that "woefully little is known 
about the migratory habitats of the vast majority" of bird species in temperate South America. Although temperature and rainfall likely play key roles governing migration in this region (Dingle, 2008), how these interact and how they influence migration routes in different lineages is not clear. And while Joseph (1997) distinguished between austral migrants that wintered in tropical regions of South America (South American Temperate-Tropical migration $=$ SATT $)$ and those that wintered in temperate regions (South American Cool-Temperate migration $=\mathrm{SACT}$ ), this generality obscures the fact that there is a greater diversity of migration patterns in temperate South American than in temperate North America, which likely reflects a combination of lineage history and relative geographic area; temperate South America is much smaller than temperate North America, and much closer to the target areas in tropical South America. As such, migrants from austral regions do not have as far to travel (Chesser, 1994), and they probably disperse more widely in non-breeding habitat (Faaborg et al., 2010), which exacerbates efforts to resolve migration patterns there. Hence, we have limited information on where birds go when they leave Fray Jorge, other than "north" or "over the Andes". Given these deep limitations to making progress in understanding this area, we agree with Jahn et al. (2004) that developing an international consortium to promote and monitor research on Austral migrations would be a tremendous step forward. Within Chile, the presence of a network of long-term research stations with existing avian data bases (http://www.ieb-chile.cl/index.php/main/seccion/111) provides opportunities for spatially broad efforts, and would appear to provide an ideal base for collaborative efforts with Argentinian ornithologists (e.g., Ñacuñan Biosphere Reserve (Cueto et al., 2008) and other sites in temperate and subpolar Argentina).

The timing and movements of birds is also poorly understood. Is Fray Jorge an important migration refueling stop for transient birds migrating to the north or south? When are the transition periods for migration in the Austral spring and fall? How are resident birds affected by the influx of wintering species? These questions among others remain unresolved for this avifauna, and underscore the need 
for additional work to understand migration in temperate South America. We do know that a number of species occur at Fray Jorge seasonally and predictably, albeit in varying numbers from year to year, including the White-crested Elaenia, the Dark-faced Ground-Tyrant, the Rufous-tailed Plantcutter, and the Giant Hummingbird. The White-crested Elaenia summers in southern Chile but migrates north to Peru and eastern (Amazonian) Brazil (Fjeldså and Krabbe, 1990; Ridgely and Tudor, 1994), but the route taken and the underlying mechanisms promoting this, as well as the physiological toll, is poorly known. Similarly, Dark-faced Ground-Tyrants breed in southern Chile and Argentina, then migrate north to Peru and Uruguay (Ridgely and Tudor, 1994), but little is known beyond this rough sketch.

In addition to these migrants, there is another group of species that appears to be expanding their ranges from northern Chile, such as the Oasis Hummingbird and West Peruvian Dove, or from the Andes, the Rufous-banded and Creamy-rumped miners, and Crag Chilia. Only further study will yield insight to the dynamics of these expansions, the extent to which they are bona fide expansions (vs. partial or differential migrations --- Dingle, 1996), the mechanism(s) underlying these dispersal patterns, and the extent to which this may be influenced by climate change (e.g., Cox, 2010; Møller et al., 2010). This is an area of productive and important research for which Fray Jorge provides an important base for ongoing efforts.

\subsection{Threats to the avifauna of the Norte Chico.}

North-central Chile has a multi-century history of anthropogenic influences. Bahre (1979) titled his seminal study "Destruction of the natural vegetation of North-Central Chile" in reference to "the cumulative effects of centuries of man's impact on the land" (p. 53); the history of vegetative degradation in this region is sufficiently deep that the impacts on avian communities likely are historic at this point. However, recent impacts may have substantial impacts on the regional avifauna. These include "reforestation" of degraded lands with various species of Atriplex, most of which are not native 
to Chile and which are planted in raised furrows to take advantage of rainfall (Alonso, 1990), agricultural growth associated with tremendous increases in the application of agricultural pesticides (see RamírezSantana et al., 2014) with potential impact on bird species (Estades et al., 2007), and growth in the human population and associated urban development (INE, no date). The most recent potential threat is the rapid expansion of wind energy facilities in Chile (Anonymous, 2014; Azzopardi, 2014). In June 2014 commercial operations commenced at Chile's largest wind energy facility, El Arrayán (PowerTechnology.com, 2014), located just north of Fray Jorge and consisting of 50 independent turbines. Much of the energy from this facility is directed to copper mines in northern Chile, with about one-third contributing to general Chilean electricity needs. Wind energy has seen tremendous growth globally in recent years and has been roughly paralleled with papers addressing the impacts of wind energy on birds and bats. To our knowledge, no such work has been pursued in Chile; we urge funding of research on this theme. Results elsewhere are somewhat mixed. In North America 140,000 to 328,000 birds are estimated to be killed annually by colliding with turbines (Loss et al., 2013); while this is less than some other hazards such as communication towers, buildings, agricultural pesticides, and domestic and feral cats (Subramanian, 2012), the mortality is not random across avian groups, and impacts raptors and migratory species disproportionately (de Lucas et al., 2008; Smallwood and Thelander, 2008; Farfán et al., 2009; Smallwood and Karas, 2009; Pagel et al., 2013). Additionally, displacement caused by secondary effects of habitat disturbance is substantial (e.g., Stevens et al., 2013) and mortality patterns may differ during and after construction (Pearce-Higgins et al., 2012; Bull et al., 2013). Additionally, several bat species appear disproportionately impacted by wind turbines (Kunz et al., 2007; Arnett et al., 2008). Fortunately, careful management and site selection can greatly reduce wildlife impacts with only trivial economic consequences (see Subramanian, 2012). Research on the impacts of wind farms on wildlife is needed in Chile, and we urge such research to emphasize the need for "win-win" solutions 
that allow for the unavoidable growth in energy needs while minimizing deleterious consequences for birds and bats.

\section{Conclusions.}

Chile's Coquimbo Region has a fascinating avifauna and numerous locations such as Fray Jorge which provide outstanding natural laboratories for both natural and artificial experiments. Temperate birds in South America have evolved as a scientifically productive semi-independent experiment for comparison with those of North America as well as other temperate regions. Ecological, demographic and morphologic comparisons could be explored for suspected analogs such as: Anna's Hummingbird (Calypte anna) and Green-backed Firecrown, Wrentit (Chamaea fasciata) and Dusky-tailed Canastero, Ladder-backed Woodpecker (Dryobates scalaris) and Striped Woodpecker, California Thrasher (Toxostoma redivivum) and Scale-throated Earthcreeper, Loggerhead Shrike (Lanius ludovicianus) and Great Shrike-Tyrant, to name a few. Chile, in particular, provides a compelling comparison with western North America, a fact that was not missed in the heyday of the IBP program (Mooney, 1977). Nearly 40 years later, we know much more about this fauna but much remains to be learned. We hope that this contribution will attract additional investigators to this understudied gem.

\section{Acknowledgments}

The research reported here from Fray Jorge has been generously supported by the personnel and administration of the Corporación Nacional Forestal (CONAF). Financial support to DAK and PLM has come largely from the U.S. National Science Foundation (most recently, NSF-LTREB DEB 1456729), and to RM, VQ, and RAV from FONDECYT (1220155 to RM, 3110059 and 11130245 to VQ, 1090794 and 1140548 to RAV). RAV also acknowledges the Instituto de Ecología y Biodiversidad (IEB - P05-002-ICM, PBF-23-CONICYT). Additionally, we acknowledge institutional support from Northern Illinois University, the University of California Davis, the Universidad de La Serena, Universidad Católica, Universidad de 
Chile, the Instituto de Ecología y Biodiversidad (IEB - Santiago, Chile, grants P05-002-ICM, PBF-23CONICYT), the Centro de Estudios Avanzados en Zonas Áridas (CEAZA - La Serena, Chile), the UC Davis Selma Herr Fund for Ornithology, and institutional support to the Museum of Wildlife and Fish Biology in the Department of Wildlife, Fish, and Conservation Biology, UC Davis.

\section{Literature Cited}

Aizen, M.A., Ezcurra, C., 1998. High incidence of plant-animal mutualisms in the woody flora of the temperate forest of southern South America: biogeographical origin and present ecological significance. Ecologia Austral 8, 217-236.

Alonso, J.L., 1990. Reforestation of arid and semi-arid zones in Chile. Agriculture Ecosystems and Environment 33, 111-128.

Amico, G.C., Vidal-Russell, R., Nickrent, D.L., 2007. Phylogenetic relationships and ecological speciation in the mistletoe Tristerix (Loranthaceae): the influence of pollinators, dispersers, and hosts. American Journal of Botany 94, 558-567.

Anonymous, 2014. Latin America Report: how Chile Is shepherding its renewable energy expansion, RenewableEnergyWorld.com.

Antonioletti R., R., Schneider S., H., Borcosque D., J.L., Zarate C., E., 1972. Características climáticas del Norte Chico ( $26^{\circ}$ a $33^{\circ}$ latitud sur). Instituto de Investigación de Recursos Naturales (IREN), Santiago, Chile.

Arnett, E.B., Brown, W.K., Erickson, W.P., Fiedler, J.K., Hamilton, B.L., Henry, T.H., Jain, A., Johnson, G.D., Kerns, J., Koford, R.R., Nicholson, C.P., O'Connell, T.J., Piorkowski, M.D., Tankersley, R.D., Jr., 2008. Patterns of bat fatalities at wind energy facilities in North America. Journal of Wildlife Management 72, 61-78. 
Arroyo, M.T.K., Marquet, P., Marticorena, C., Simonetti, J., Cavieres, L., Squeo, F., Rozzi, R., Massardo, F., 2006. El hotspot Chileno, prioridad mundial para la conservación, Biodiversidad de Chile: patrimonios y desafíos. Ocho Libros Editores, Santiago, Chile, pp. 94-97.

Azzopardi, T., 2014. Analysis: Envison plans expansion into South America, WindPower Monthly, available at http://www.windpowermonthly.com/article/1314472/analysis-envison-plans-expansionsouth-america.

Bahre, C.J., 1979. Destruction of the natural vegetation of north-central Chile. University of California Publications in Geography 23, 1-117.

Barbosa, O., Marquet, P.A., Bacigalupe, L.D., Christie, D.A., del-Val, E., Gutierrez, A.G., Jones, C.G., Weathers, K.C., Armesto, J.J., 2010. Interactions among patch area, forest structure and water fluxes in a fog-inundated forest ecosystem in semi-arid Chile. Functional Ecology 24, 909-917.

Bartholomeus, R.P., Witte, J.-P.M., van Bodegom, P.M., van Dam, J.C., Aerts, R., 2011. Climate change threatens endangered plant species by stronger and interacting water-related stresses. Journal of Geophysical Research: Biogeosciences 116, G04023.

Beals, E.W., 1984. Bray-Curtis ordination: an effective strategy for analysis of multivariate ecological data. Advances in Ecological Research 14, 1-55.

BirdLife International, 2014. Country profile: Chile. Available from: http://www.birdlife.org/datazone/country/chile. Checked: 2014-12-17.

Botto-Mahan, C., Medel, R., Ginocchio, R., Montenegro, G., 2000. Factors affecting the circular distribution of the leafless mistletoe Tristerix aphyllus (Loranthaceae) on the cactus Echinopsis chilensis. Revista Chilena de Historia Natural 73, 525-531.

Brown, J.H., Kodric-Brown, A., 1977. Turnover rates in insular biogeography: effect of immigration on extinction. Ecology 58, 445-449. 
Bull, L.S., Fuller, S., Sim, D., 2013. Post-construction avian mortality monitoring at Project West Wind. New Zealand Journal of Zoology 40, 28-46.

Chesser, R.T., 1994. Migration in South America: an overview of the austral system. Bird Conservation International 4, 91-107.

Cofré, H.L., Boehning-Gaese, K., Marquet, P.A., 2007. Rarity in Chilean forest birds: which ecological and life-history traits matter? Diversity and Distributions 13, 203-212.

CONAF, 1998. Plan de manejo Parque Nacional Bosque Fray Jorge. Documento de trabajo \#297. República de Chile, Ministerio de Agricultura, Corporación Nacional Forestal IV Región, Coquimbo, Chile.

CONAF, No date. Plan de desarrollo ecoturístico Parque Nacional Bosque Fray Jorge Región de Coquimbo. Corporación Nacional Forestal, Región de Coquimbo. 98 pages (http://www.bosquefrayjorge.cl/ accessed 3 October 2014).

CONAMA, 2006. Estudio de la variabilidad climática en Chile para el Siglo XXI. Informe final. Comisión Nacional del Medio Ambiente, Santiago, Chile (online at http://www.dgf.uchile.cl/PRECIS/articles39442 pdf Estudio texto.pdf).

Cooke, K., 2015. Chile faces "critical situation" as floods and droughts batter country. RTCC (Responding to Climate Change)(http://www.rtcc.org/2015/03/31/chile-faces-critical-situation-as-floods-anddroughts-batter-country/; accessed 6 May 2015).

CORFO, 1950. Geografía económica de Chile. Tomo 1. Corporación de Fomento de la Produccion, Santiago, Chile.

Cornelius, C., Cofré, H., Marquet, P.A., 2000. Effects of habitat fragmentation on bird species in a relict temperate forest in semiarid Chile. Conservation Biology 14, 534-543.

Cox, G.W., 2010. Bird migration and global change. Island Press, Washington, DC. 
Cueto, V.R., Lopez De Casenave, J., Marone, L., 2008. Neotropical austral migrant landbirds: population trends and habitat use in the central Monte Desert, Argentina. Condor 110, 70-79.

de Lucas, M., Janss, G.F.E., Whitfield, D.P., Ferrer, M., 2008. Collision fatality of raptors in wind farms does not depend on raptor abundance. Journal of Applied Ecology 45, 1695-1703.

De Santo, T.L., Willson, M.E., Sieving, K.E., Armesto, J.J., 2002. Nesting biology of tapaculos (Rhinocryptidae) in fragmented south-temperate rainforests of Chile. Condor 104, 482-495. del-Val, E., Armesto, J.J., Barbosa, O., Christie, D.A., Gutiérrez, A.G., Jones, C.G., Marquet, P.A., Weathers, K.C., 2006. Rain forest islands in the Chilean semiarid region: fog-dependency, ecosystem persistence and tree regeneration. Ecosystems 9, 598-608.

del-Val, E., Armesto, J.J., Barbosa, O., Marquet, P.A., 2007. Effects of herbivory and patch size on tree seedling survivorship in a fog-dependent coastal rainforest in semiarid Chile. Oecologia (Berlin) 153, 625-632.

DeSante, D.F., Kaschube, D.R., 2007. The Monitoring Avian Productivity and Survivorship (MAPS) program 2002 and 2003 report. Bird Populations 8, 46-115.

Dingle, H., 1996. Migration : the biology of life on the move. Oxford University Press, New York.

Dingle, H., 2008. Bird migration in the southern hemisphere: a review comparing continents. Emu 108, 341-359.

Dufrêne, M., Legendre, P., 1997. Species assemblages and indicator species: the need for a flexible asymmetrical approach. Ecological Monographs 67, 345-366.

Engilis, A., Jr., Kelt, D.A., 2009. Foraging behavior of tufted tit-tyrants (Anairetes parulus) in semiarid northcentral Chile. Wilson Journal of Ornithology 121, 585-592.

Engilis, A., Jr., Kelt, D.A., 2011. Foraging behavior of Plain-mantled Tit-spinetail (Leptasthenura aegithaloides) in semiarid scrublands, north-central Chile. Ornitologia Neotropical 22, 247-256. 
Esposito, A., 2015. Chile says drought here to stay, lays out plan to ensure water. Reuters

(http://www.reuters.com/article/2015/03/24/us-chile-drought-idUSKBNOMK2HJ20150324; accessed 6 May 2015).

Estades, C.F., 1997. Bird-habitat relationships in a vegetational gradient in the Andes of central Chile. Condor 99, 719-727.

Estades, C.F., Aguirre, J., Escobar, M.A.H., Tomasevic, J.A., Vukasovic, M.A., Tala, C., 2007. Conservation status of the Chilean Woodstar Eulidia yarrellii. Bird Conservation International 17, 163-175.

Faaborg, J., Holmes, R.T., Anders, A.D., Bildstein, K.L., Dugger, K.M., Gauthreaux, S.A., Heglund, P., Hobson, K.A., Jahn, A.E., Johnson, D.H., Latta, S.C., Levey, D.J., Marra, P.P., Merkord, C.L., Nol, E., Rothstein, S.I., Sherry, T.W., Sillett, T.S., Thompson, F.R., Warnock, N., 2010. Recent advances in understanding migration systems of New World land birds. Ecological Monographs 80, 3-48.

Farfán, M.A., Vargas, J.M., Duarte, J., Real, R., 2009. What is the impact of wind farms on birds? A case study in southern Spain. Biodiversity and Conservation 18, 3743-3758.

Fitzpatrick, J.W., 1980. Foraging behavior of Neotropical tyrant flycatchers. Condor 82, 43-57.

Fjeldså, J., Krabbe, N., 1990. Birds of the High Andes. Zoological Museum, University of Copenhagen ; Apollo Books, Copenhagen; Svendborg, Denmark.

Gajardo, R., 1994. La vegetación natural de Chile: clasificación y distribución geográfica. Editorial Universitaria, Santiago de Chile.

Guerra, T.J., Pizo, M.A., 2014. Asymmetrical Dependence Between a Neotropical Mistletoe and its Avian Seed Disperser. Biotropica 46, 285-293.

Guerrero, P.C., Carvallo, G.O., Nassar, J.M., Rojas-Sandoval, J., Sanz, V., Medel, R., 2012. Ecology and evolution of negative and positive interactions in Cactaceae: lessons and pending tasks. Plant Ecology \& Diversity 5, 205-215. 
Gutiérrez, A.G., Barbosa, O., Christie, D.A., del-Val, E.K., Ewing, H.A., Jones, C.G., Marquet, P.A., Weathers, K.C., Armesto, J.J., 2008. Regeneration patterns and persistence of the fog-dependent Fray Jorge forest in semiarid Chile during the past two centuries. Global Change Biology 14, 161-176.

Gutiérrez, J.R., Meserve, P.L., Kelt, D.A., Engilis, J., Andrew, Previtali, M.A., Milstead, W.B., Jaksic, F.M., 2010. Long-term research in Bosque Fray Jorge National Park: twenty years studying the role of biotic and abiotic factors in a Chilean semiarid scrubland. Revista Chilena de Historia Natural 83, 69-98.

Hellmayr, C.E., 1932. The birds of Chile. Field Mus Nat Hist Publ 308 Zool Ser 19, 5-472.

Holmgren, M., 2002. Exotic herbivores as drivers of plant invasion and switch to ecosystem alternative states. Biological Invasions 4, 25-33.

INE, no date. Población, país y regionles actualización población 2002-2012 y proyecciones 2013-2020. Instituto Nacional de Estadisticas, Santiago, Chile. Available at http://www.ine.cl/canales/chile estadistico/familias/demograficas vitales.php (accessed 17 December 2014).

Ippi, S., van Dongen, W.F.D., Lazzoni, I., Venegas, C.I., Vásquez, R.A., 2013. Interpopulation comparisons of antipredator defense behavior of the Thorn-tailed Rayadito (Aphrastura spinicauda). Ethology 119, $1-11$.

Ippi, S., Vasquez, R.A., van Dongen, W.F.D., Lazzoni, I., 2011. Geographical variation in the vocalizations of the suboscine Thorn-tailed Rayadito Aphrastura spinicauda. Ibis 153, 789-805.

Jahn, A.E., Levey, D.J., Smith, K.G., 2004. Reflections across hemispheres: a system-wide approach to new world bird migration. Auk 121, 1005-1013.

Jaksic, F.M., 2001. Ecological effects of El Nino in terrestrial ecosystems of western South America. Ecography 24, 241-250.

Jaksic, F.M., Lazo, I., 1999. Response of a bird assemblage in semiarid Chile to the 1997-1998 El Niño. Wilson Bulletin 111, 527-535. 
Jaksic, F.M., Silva-Aranguiz, E., Silva, S.I., 2004. Fauna del Parque Nacional Bosque Fray Jorge: una revision bibliográfica, in: Squeo, F.A., Gutiérrez, J.R., Hernández, I.R. (Eds.), Historia Natural del Parque Nacional Bosque Fray Jorge Ediciones Universidad de La Serena, La Serena, Chile, pp. 93-114. James, F.C., McCulloch, C.E., 1990. Multivariate analysis in ecology and systematics: Panacea or Pandora's box? Annual Review of Ecology and Systematics 21, 129-166.

Jaramillo, A., Barros, R., 2013. Species lists of birds for South American countries and territories: Chile. Version 30, 26 August 2013. http://www.museum.Isu.edu/ Remsen/SACCCountryLists.html. Jaramillo, A., Burke, P., Beadle, D., 2003. Birds of Chile. Princeton University Press, Princeton, N.J. Joseph, L., 1997. Towards a broader view of neotropical migrants: Consequences of a re-examination of austral migration. Ornitologia Neotropical 8, 31-36.

Kelt, D.A., Engilis, A., Jr., Monárdez, J., Walsh, R., Meserve, P.L., Gutiérrez, J.R., 2012. Seasonal and multiannual patterns in avian assemblage structure and composition in northern Chilean thorn-scrub. Condor $114,30-43$.

Koeppen, W., 1948. Climatología: con un estudio de los climas de la tierra. Fondo de Cultura Económica, México.

Kunz, T.H., Arnett, E.B., Cooper, B.M., Erickson, W.P., Larkin, R.P., Mabee, T., Morrison, M.L., Strickland, M.D., Szewczak, J.M., 2007. Assessing impacts of wind-energy development on nocturnally active birds and bats: A guidance document. Journal of Wildlife Management 71, 2449-2486.

Loss, S.R., Will, T., Marra, P.P., 2013. Estimates of bird collision mortality at wind facilities in the contiguous United States. Biological Conservation 168, 201-209.

Lowther, P., Post, W., 1999. Shiny cowbird (Molothrus bonariensis) Birds of North America online (retrieved 15 June 2011 from http://bna.birds.cornell.edu/bna/species/399). Luebert, F., Pliscoff, P., 2006. Sinopsis bioclimática y vegetacional de Chile. Editorial Universitaria, Santiago de Chile. 
Madrigal, J., Kelt, D.A., Meserve, P.L., Gutiérrez, J.R., Squeo, F.A., 2011. Bottom-up control of consumers leads to top-down indirect facilitation of invasive herbs in arid Chile. Ecology 92, 282-288.

Martínez del Rio, C., Hourdequin, M., Silva, A., Medel, R., 1995. The influence of cactus size and previous infection on bird deposition of mistletoe seeds. Australian Journal of Ecology 20, 571-576.

Martínez del Rio, C., Silva, A., Medel, R., Hourdequin, M., 1996. Seed dispersers as disease vectors: bird transmission of mistletoe seeds to plant hosts. Ecology (Washington D C) 77, 912-921.

McCune, B., Grace, J.B., Urban, D.L., 2002. Analysis of ecological communities. MjM Software Design, Gleneden Beach, OR.

McCune, B., Mefford, M.J., 2011. PC-ORD. Multivariate analysis of ecological data. Version 6.17. MjM Software, Gleneden Beach, Oregon, USA.

Medel, R., 2000. Assessment of parasite-mediated selection in a host-parasite system in plants. Ecology (Washington D C) 81, 1554-1564.

Medel, R., 2001. Assessment of correlational selection on tolerance and resistance traits in a host plantparasitic plant interaction. Evolutionary Ecology 15, 37-52.

Medel, R., Botto-Mahan, C., Smith-Ramirez, C., Mendez, M.A., Ossa, C.G., Caputo, L., Gonzales, W.L., 2002. Quantitative natural history of a host-parasite relationship: The Tristerix-cactus system in semiarid Chile. Revista Chilena de Historia Natural 75, 127-140.

Medel, R., Mendez, M., Ossa, C., Botto-Mahan, C., 2010. Arms race coevolution: the local and geographical structure of a host-parasite interaction. Evolution: Education and Outreach, 3, 26-31.

Medel, R., Vergara, E., Silva, A., Kalin-Arroyo, M., 2004. Effects of vector behavior and host resistance on mistletoe aggregation. Ecology 85, 120-126.

Medel, R.G., Vergara, E., Silva, A., Serey, I.A., 1995. Variation of the architectural phenotype of Tristerix aphyllus in central Chile. Revista Chilena de Historia Natural 68, 451-458. 
Meserve, P.L., Gutiérrez, J.R., Kelt, D.A., Previtali, M.A., Engilis, J., Andrew, Milstead, W.B., 2009. Global climate change and biotic-abiotic interactions in the northern Chilean semiarid zone: potential longterm consequences of increased El Niños, in: Long, J.A., Wells, D.S. (Eds.), Ocean circulation and El Nino: new research. Nova Science Publishers, New York, pp. 139-162.

Meserve, P.L., Kelt, D.A., Milstead, W.B., Gutiérrez, J.R., 2003. Thirteen years of shifting top-down and bottom-up control. Bioscience 53, 633-646.

Meyer de Schauensee, R.E.E., 1966. The species of birds of South America and their distribution. Academy of Natural Sciences, Philadelphia, Pennsylvania, USA.

Mittermeier, R.A., Myers, N., Goettsch Mittermeier, C., Robles Gil, P., 1999. Hotspots: earth's biologically richest and most endangered terrestrial ecoregions. CEMEX; Conservation International, Mexico City. Møller, A.P., Wolfgang, F., Berthold, P., 2010. Effects of climate change on birds. Oxford University Press, New York.

Mooney, H.A., 1977. Convergent evolution in Chile and California : Mediterranean climate ecosystems. Dowden, Hutchinson \& Ross ; Exclusive distributor Halsted Press, Stroudsburg, Pa.; [New York].

Moreno, J., Merino, S., Lobato, E., Rodríguez-Girones, M.A., Vásquez, R.A., 2007. Sexual dimorphism and parental roles in the Thorn-tailed Rayadito (Furnariidae). Condor 109, 312-320.

Moreno, J., Merino, S., Vásquez, R.A., Armesto, J.J., 2005. Breeding biology of the Thorn-tailed Rayadito (Furnariidae) in south-temperate rainforests of Chile. Condor 107, 69-77.

Morrison, J.L., Phillips, L.M., 2000. Nesting habitat and success of the Chimango Caracara in southern Chile. Wilson Bulletin 112, 225-232.

Myers, N., Mittermeier, R.A., Mittermeier, C.G., da Fonseca, G.A.B., Kent, J., 2000. Biodiversity hotspots for conservation priorities. Nature 403, 853-858. 
Nunez-Avila, M.C., Uriarte, M., Marquet, P.A., Armesto, J.J., 2013. Decomposing recruitment limitation for an avian-dispersed rain forest tree in an anciently fragmented landscape. Journal of Ecology 101, $1439-1448$.

Pagel, J.E., Kritz, K.J., Millsap, B.A., Murphy, R.K., Kershner, E.L., Covington, S., 2013. Bald eagle and golden eagle mortalities at wind energy facilities in the contiguous United States. Journal of Raptor Research 47, 311-315.

Pearce-Higgins, J.W., Stephen, L., Douse, A., Langston, R.H.W., 2012. Greater impacts of wind farms on bird populations during construction than subsequent operation: results of a multi-site and multispecies analysis. Journal of Applied Ecology 49, 386-394.

Power-Technology.com, 2014. El Arrayán wind farm Chile. Available at http://www.powertechnology.com/projects/el-arrayn-wind-farm/ (accessed 17 December 2014).

Prentice, I.C., 1977. Non-metric ordination methods in ecology. Journal of Ecology 65, 85-94.

Previtali, M.A., Meserve, P.L., Kelt, D.A., Milstead, W.B., Gutiérrez, J.R., 2010. Effects of more frequent and prolonged El Niño events on life history parameters of the degu, a long-lived and slowreproducing rodent. Conservation Biology 24, 18-28.

Pyle, P., 1997. Identification guide to North American birds. Part I. Columbidae to Ploceidae. Slate Creek Press, Bolinas (California).

Pyle, P., Engilis, A., Jr., Kelt, D.A., 2015a. Manual for ageing and sexing birds of Bosque Fray Jorge National Park and Northcentral Chile, with notes on range and breeding seasonality. Occasional Papers of the LSU Museum of Natural Science.

Pyle, P., Engilis, A., Jr., Kelt, D.A., 2015b. Manual para estimar edad y sexo de aves terrestres del Parque Nacional Bosque Fray Jorge y Chile Central, con notas sobre rangos de distribución y estación reproductiva. Special Publication of the Occasional Papers of the Museum of Natural Science. 
Quilodran, C.S., Estades, C.F., Vásquez, R.A., 2014. Conspecific effect on habitat selection of a territorial cavity-nesting bird. Wilson Journal of Ornithology 126, 534-543.

Quilodran, C.S., Vasquez, R.A., Estades, C.F., 2012. Nesting of the thorn-tailed rayadito (Aphrastura spinicauda) in a pine plantation in south-central Chile. Wilson Journal of Ornithology 124, 737-742.

Quirici, V., Guerrero, C.J., González, P., Krause, J., Wingfield, J.C., Vásquez, R.A., 2014a. Baseline CORT levels in the Thor-tailed Rayadito (Aphrastura spinicauda) and telomere length follows the same trend between populations. IV Congreso Colombiano de Zoología, Cartagena, Colombia.

Quirici, V., Venegas, C.I., González-Gómez, P.L., Castaño-Villa, G., Wingfield, J.C., Vásquez, R.A., 2014b. Baseline corticosterone and stress response in the Thorn-tailed Rayadito (Aphrastura spinicauda) along a latitudinal gradient. General and Comparative Endocrinology 198, 39-46.

Ramírez-Santana, M., Iglesias-Guerrero, J., Castillo-Riquelme, M., Scheepers, P.T.J., 2014. Assessment of health care and economic costs due to episodes of acute pesticide intoxication in workers of rural areas of the Coquimbo Region, Chile. Value in Health Regional Issues 5C, 35-39.

Reid, S., Cornelius, C., Barbosa, O., Meynard, C., Silva-Garcia, C., Marquet, P.A., 2002. Conservation of temperate forest birds in Chile: implications from the study of an isolated forest relict. Biodiversity and Conservation 11, 1975-1990.

Remsen, J.V., Cadena, C.D., Jaramillo, A., Nores, M., Pacheco, J.F., Pérez-Emán, J., Robbins, M.B., Stiles, F.G., Stotz, D.F., Zimmer, K.J., 2014. A classification of the bird species of South America (Version 6 October 2014). American Ornithologists' Union. http://www.museum.Isu.edu/ Remsen/SACCBaseline.html.

Ridgely, R.S., Tudor, G., 1994. The birds of South America. Vol. 2. The suboscine passerines. University of Texas Press, Austin, Texas.

Silva, A., Martínez del Rio, C., 1996. Effects of the mistletoe Tristerix aphyllus (Loranthaceae) on the reproduction of its cactus host Echinopsis chilensis. Oikos 75, 437-442. 
Silvertown, J., Araya, Y., Gowing, D., 2015. Hydrological niches in terrestrial plant communities: a review. Journal of Ecology 103, 93-108.

Smallwood, K.S., Karas, B., 2009. Avian and Bat Fatality Rates at Old-Generation and Repowered Wind Turbines in California. Journal of Wildlife Management 73, 1062-1071.

Smallwood, K.S., Thelander, C., 2008. Bird Mortality in the Altamont Pass Wind Resource Area, California. The Journal of Wildlife Management 72, 215-223.

Squeo, F.A., Gutierrez, J.R., Hernández, I.R., 2004. Historia Natural del Parque Nacional Bosque Fray Jorge. Ediciones Universidad de La Serena, La Serena, Chile.

Stanton, D.E., Armesto, J.J., Hedin, L.O., 2014. Ecosystem properties self-organize in response to a directional fog-vegetation interaction. Ecology 95, 1203-1212.

Stevens, T.K., Hale, A.M., Karsten, K.B., Bennett, V.J., 2013. An analysis of displacement from wind turbines in a wintering grassland bird community. Biodiversity and Conservation 22, 1755-1767.

Subramanian, M., 2012. The trouble with turbines: an ill wind. Nature 486, 310-311.

Thomas, L., Buckland, S.T., Rexstad, E.A., Laake, J.L., Strindberg, S., Hedley, S.L., Bishop, J.R.B., Marques, T.A., Burnham, K.P., 2010. Distance software: design and analysis of distance sampling surveys for estimating population size. Journal of Applied Ecology 47, 5-14.

Tyler, S., 2004. Correndera Pipit (Anthus correndera), in: del Joyo, J., Elliott, A., Sarfatal, J., Christie, D.A., de Juana, E. (Eds.), Handbook of the birds of the world alive. Lynx Edicions, Barcelona, Spain. Retrieved from http://www.hbw.com/node/57793 on 8 December 2014.

Vergara, P.M., Marquet, P.A., 2007. On the seasonal effect of landscape structure on a bird species: the thorn-tailed rayadito in a relict forest in northern Chile. Landscape Ecology 22, 1059-1071.

Vilina, Y., Cofré, H., 2006. Aves terrestres, Biodiversidad de Chile: patrimonio y desafíos. Ocho Libros Editores, Santiago, Chile, pp. 249-257. 
Villagrán, C., Armesto, J.J., Hinojosa, L.F., Cuvertino, J., Pérez, C., Medina, C., 2004. El enigmático origen del bosque relicto de Fray Jorge, in: Squeo, F.A., Gutiérrez, J.R., Hernández, I.R. (Eds.), Historia Natural del Parque Nacional Bosque Fray Jorge. Ediciones Universidad de La Serena, La Serena, Chile, pp. 3-43.

Watson, D.M., Rawsthorne, J., 2013. Mistletoe specialist frugivores: latterday 'Johnny Appleseeds' or self-serving market gardeners? Oecologia (Berlin) 172, 925-932.

Willson, M.F., Armeston, J.J., Díaz, I.A., Ojeda, V., Celis-Diez, J.L., 2014. Chucao y otras aves del bosque templado lluvioso de Sudamérica. Corporación Instituto de Ecología y Biodiversidad, Santiago, Chile.

Willson, M.F., De Santo, T.I., Sabag, C., Armesto, J.J., 1994. Avian communities of fragmented southtemperate rainforests in Chile. Conservation Biology 8, 508-520.

Willson, M.F., De Santo, T.L., Sabag, C., Armesto, J.J., 1995. Avian communities in temperate rainforests of North and South America, in: Lawford, R.G., Alaback, P.B., Fuentes, E. (Eds.), Ecological Studies; High-altitude rainforests and associated ecosystems of the West Coast of the Americas: Climate, hydrology, ecology, and conservation. Springer-Verlag New York, Inc., 175 Fifth Avenue, New York, New York 10010, USA Heidelberger Platz 3, D-1000 Berlin, Germany, pp. 228-247.

Yanez, J.L., Nunez, H., Schlatter, R.P., Jaksic, F.M., 1980. Diet and weight of American kestrels in central Chile. Auk 97, 629-631. 
Table 1. Results of indicator species analysis, showing the 20 species for which the probability of a higher IV value was $<0.10$. Seven of these species (denoted with asterisks) are year-round residents of the site and so their indicator status reflects seasonal detectability rather than true changes; other species exhibit seasonal changes in numbers, reflecting migratory patterns. Note that the overall mean includes all 41 species analyzed (denoted in Appendix 1 with asterisks; see also Supplemental Table 1).

\begin{tabular}{|c|c|c|c|}
\hline Species & $\begin{array}{l}\text { Indicator } \\
\text { Value (IV) }\end{array}$ & $\begin{array}{l}\text { Mean (SD) IV from } \\
\text { Randomization }\end{array}$ & $\boldsymbol{P}$ \\
\hline \multicolumn{4}{|c|}{ Summer } \\
\hline Chilean Flicker (CHFL) & 27.3 & $12.8(6.90)$ & 0.0944 \\
\hline Dusky-tailed Canastero (DTCA)* & 39.1 & $36.1(1.58)$ & 0.0410 \\
\hline House Wren (SHWR) * & 47.3 & $38.2(2.76)$ & 0.0036 \\
\hline Chilean Swallow (CHSW) * & 50.0 & $40.2(4.51)$ & 0.0306 \\
\hline \multicolumn{4}{|c|}{ Winter } \\
\hline Patagonian Tyrant (PATY) & 30.0 & $12.7(6.74)$ & 0.0490 \\
\hline Austral Thrush (AUTH) & 45.1 & $34.3(7.55)$ & 0.0958 \\
\hline Gray-hooded Sierra-Finch (GHSF) & 45.1 & $34.2(7.24)$ & 0.0364 \\
\hline Chilean Tinamou $(\mathrm{CHTI}) *$ & 52.8 & $40.3(4.59)$ & 0.0098 \\
\hline Common Miner (COMI) & 59.5 & $20(8.61)$ & 0.0008 \\
\hline Mourning Sierra-Finch (MOSF) & 73.5 & $39.2(6.87)$ & 0.0002 \\
\hline Green-backed Firecrown (GBFI) & 78.2 & $42.8(6.08)$ & 0.0002 \\
\hline
\end{tabular}




\begin{tabular}{|l|c|c|c|}
\hline Scale-throated Earthcreeper (STEA) & 88.1 & $23.9(8.95)$ & 0.0002 \\
\hline \multicolumn{3}{|c|}{ Breeding } \\
\hline Dusky Tapaculo (DUTA) * & 47.5 & $39.4(3.20)$ & 0.0134 \\
\hline Black-chinned Siskin (BCSI) & 48.0 & $29.0(8.03)$ & 0.0292 \\
\hline Grassland Yellow-Finch (GYFI) & 51.5 & $26.4(10.27)$ & 0.0232 \\
\hline Eared Dove (EADO) * & 54.1 & $40.9(8.45)$ & 0.0770 \\
\hline Giant Hummingbird (GIHU) & 54.2 & $41.7(6.79)$ & 0.0536 \\
\hline Band-tailed Sierra-Finch (BTSF) & 55.4 & $42.4(4.98)$ & 0.0144 \\
\hline Chilean Pigeon (CHPI)* & 81.8 & $29.7(9.40)$ & 0.0002 \\
\hline White-crested Elaenia (WCEL) & 95.8 & $24.5(8.29)$ & 0.0002 \\
\hline Overall mean & 41.35 & $29.61(4.67)$ & 0.2639 \\
\hline
\end{tabular}




\section{Figure Legends.}

Fig. 1. Species-area relations for (a) total bird species and (b) endemic bird species based on species richness as provided by the South American Classification Committee of the American Ornithologists' Union (http://www.museum.Isu.edu/ Remsen/SACCCountryLists.htm; version 18 February 2015). Best-fit linear regression and 95\% confidence intervals are provided (respective regression slopes are 0.24 and 1.30 , and explain $36.5 \%$ and $66.6 \%$ of the variation in these data; lines were not constrained to pass through the origin).

Fig. 2. Biplot of 30 sampling sessions (Summer 2004 through Summer 2014) using the most explanatory (first and third) NMS axes. Sessions are numbered and a temporal shift in assemblage composition (arrow) is apparent in the general trajectory from the lower right quadrat of the figure to the upper left quadrat. Larger species scores (>0.50) are indicated for each axis (also visible in Fig. 3).

Fig. 3. Species vectors in ordination space using the first and third NMS axes. Species names are indicated using 4-letter abbreviations (Appendix 1). Green, red, and blue lettering indicates those species that were strong indicators for a given season; specifically, bold font indicates those that were strong indicators $(P<0.05)$ while italic font indicates those with strong trends $(P<0.10)$. The inset provides detail on species occurring very close to the origin. 
Figure. 1.
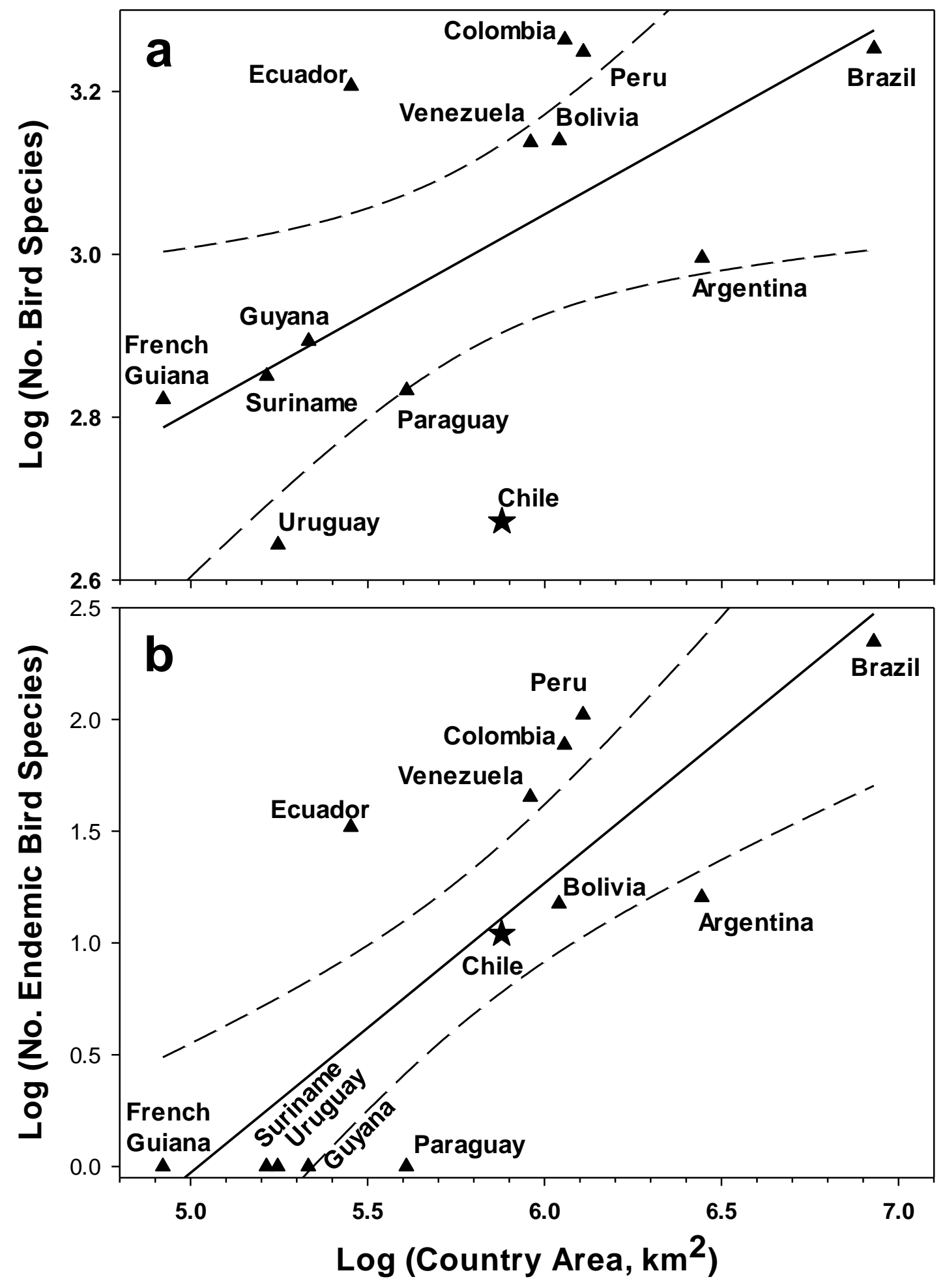

Page | 40 
Figure 2.

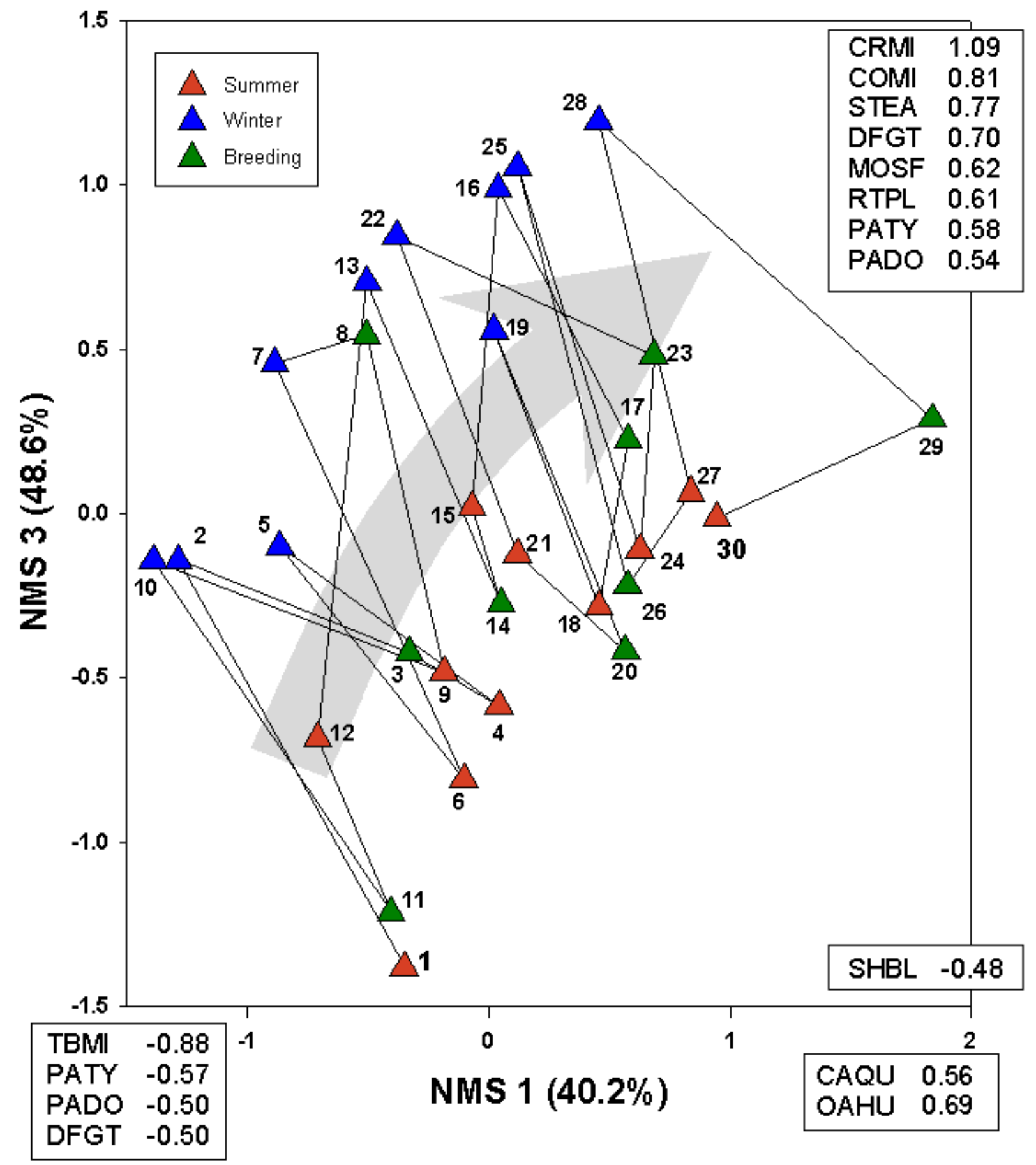


Figure 3.

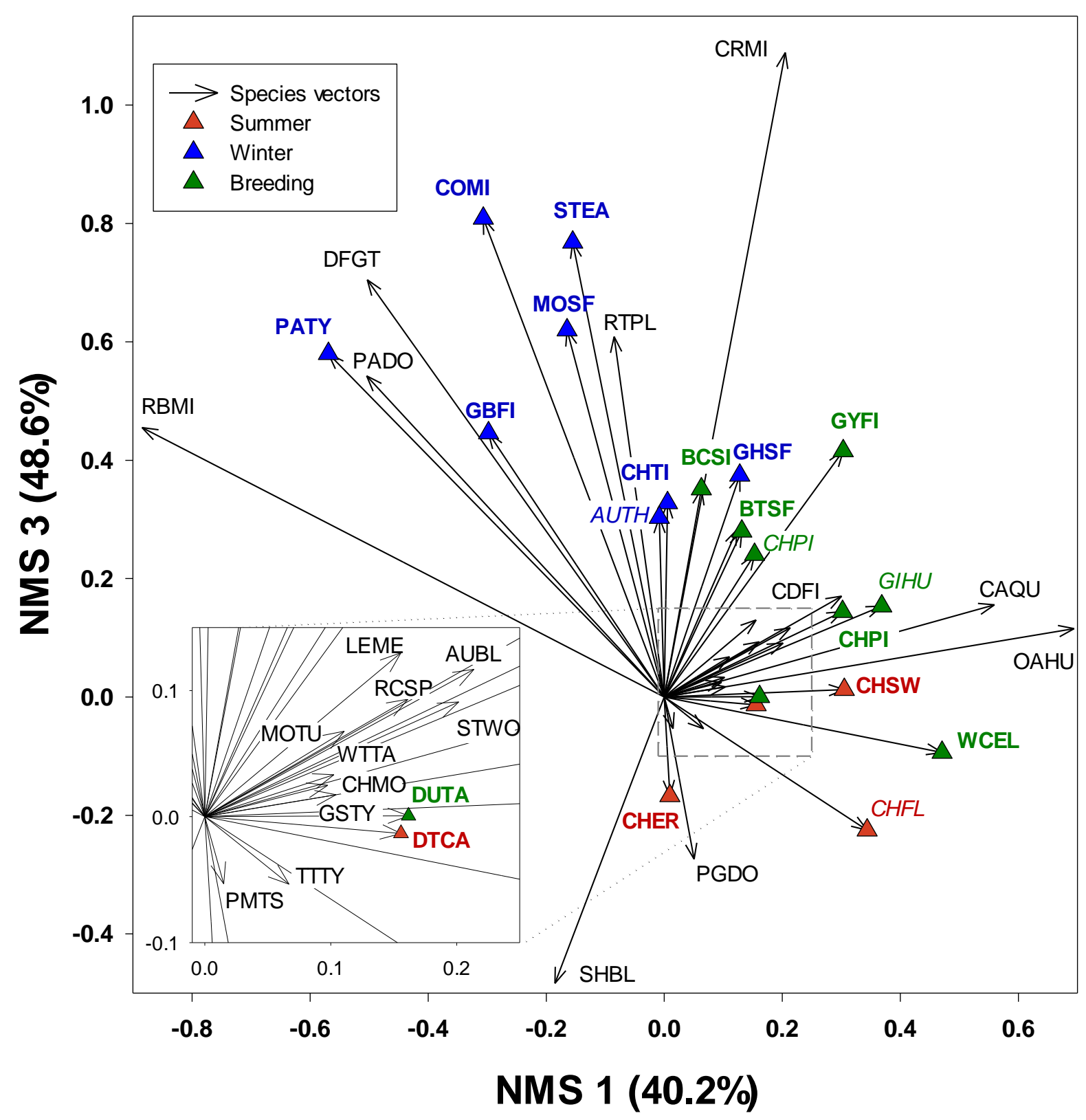




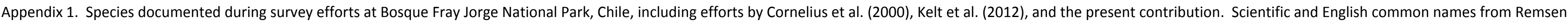

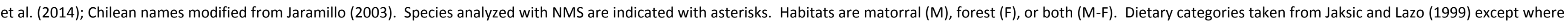

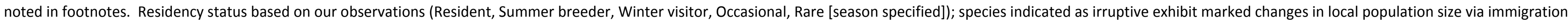

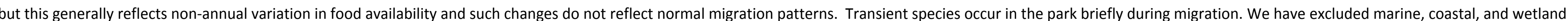
species (e.g., Peruvian Booby, Great Egret, Black-crowned Night-heron, and Plumbeous Rail have all been observed in the matorral region of Fray Jorge, albeit rarely).

\begin{tabular}{|c|c|c|c|c|c|}
\hline Order, Family & Name & Abbreviation & Habitat & Diet & Status \\
\hline \multirow[t]{2}{*}{ Tinamiformes, Tinamidae } & Chilean Tinamou / Perdiz Chilena* & CHTI & M & Gran & Resident \\
\hline & Nothoprocta perdicaria & & & & \\
\hline \multirow[t]{2}{*}{ Galliformes, Odontophoridae } & California Quail / Codorniz* & CAQU & M & Gran & Resident \\
\hline & Callipepla californica & & & & \\
\hline \multirow[t]{2}{*}{ Pelecaniformes, Threskiornithidae } & Black-faced Ibis / Bandurria & BFIB & M & Carn & Occasional \\
\hline & Theristicus melanopis & & & & \\
\hline \multirow[t]{2}{*}{ Cathartiformes, Cathartidae } & Black Vulture / Jote de Cabeza Negra & BLVU & M & Carn & Resident \\
\hline & Coragyps atratus & & & & \\
\hline Accipitriformes, Accipitridae & White-tailed Kite / Bailarín & WTKI & M & Carn & $\begin{array}{l}\text { Summer migrant, } \\
\text { irruptive }\end{array}$ \\
\hline
\end{tabular}


Elanus leucurus

\begin{tabular}{|c|c|c|c|c|c|}
\hline & Cinereous Harrier / Vari & $\mathrm{CIHA}$ & M & Carn & Occasional \\
\hline \multicolumn{6}{|c|}{ Circus cinereus } \\
\hline & Bicolored Hawk / Peuquito & BIHA & $\mathrm{F}$ & Carn & Rare, spring \\
\hline \multicolumn{6}{|c|}{ Accipiter bicolor } \\
\hline & Harris's Hawk / Peuco & HAHA & M & Carn & Resident \\
\hline \multicolumn{6}{|c|}{ Parabuteo unicinctus } \\
\hline & Black-chested Buzzard-Eagle / Águila & $\mathrm{BCBE}$ & M & Carn & Resident \\
\hline \multicolumn{6}{|c|}{ Geranoaetus melanoleucus } \\
\hline & Red-backed Hawk / Aguilucho & VAHA & M & Carn & Resident \\
\hline \multicolumn{6}{|c|}{ Geranoaetus polysoma } \\
\hline \multirow[t]{4}{*}{ Charadriiformes, Charadriidae } & Southern Lapwing / Queltehue & SOLA & M & Insect $^{3}$ & Occasional $^{\mathrm{a}}$ \\
\hline & \multicolumn{5}{|l|}{ Vanellus chilensis } \\
\hline & Slender-billed Dotterel / Chorlo de campo & SBDO & M & Insect & Occasional \\
\hline & Oreopholus ruficollis & & & & \\
\hline Columbiformes, Columbidae & Picui Ground Dove / Tortolita Cuyana* & PGDO & M & Gran & Rare year-round ${ }^{b}$ \\
\hline
\end{tabular}




\begin{tabular}{|c|c|c|c|c|c|}
\hline & Black-winged Ground-Dove / Tórtola Cordillerana & BWGD & M & Gran & Rare, spring \\
\hline \multicolumn{6}{|c|}{ Metriopelia melanoptera } \\
\hline & Chilean Pigeon / Torcaza* & $\mathrm{CHPI}$ & $\mathrm{M}-\mathrm{F}$ & Gran & Resident \\
\hline \multicolumn{6}{|c|}{ Patagioenas araucana } \\
\hline & Eared Dove / Tórtola* & EADO & $\mathrm{M}-\mathrm{F}$ & Gran & Resident \\
\hline \multicolumn{6}{|c|}{ Zenaida auriculata } \\
\hline & $\begin{array}{l}\text { West Peruvian (Pacific) Dove / Paloma de Alas } \\
\text { Blancas* }\end{array}$ & PADO & M & Gran & $\begin{array}{l}\text { Occasional but } \\
\text { increasing }^{c}\end{array}$ \\
\hline & Zenaida meloda & & & & \\
\hline \multirow[t]{2}{*}{ Strigiformes, Tytonidae } & Barn Owl / Lechuza & BAOW & M & Carn & Resident \\
\hline & Tyto alba & & & & \\
\hline \multirow[t]{5}{*}{ Strigiformes, Strigidae } & Great Horned Owl / Tucúquere & GHOW & $\mathrm{M}-\mathrm{F}$ & Carn & Resident \\
\hline & \multicolumn{5}{|l|}{ Bubo virginianus } \\
\hline & Short-eared Owl / Nuco & SEOW & M & Carn & Resident \\
\hline & \multicolumn{5}{|l|}{ Asio flammeus } \\
\hline & Burrowing Owl / Pequén & BUOW & M & Carn & Resident \\
\hline
\end{tabular}




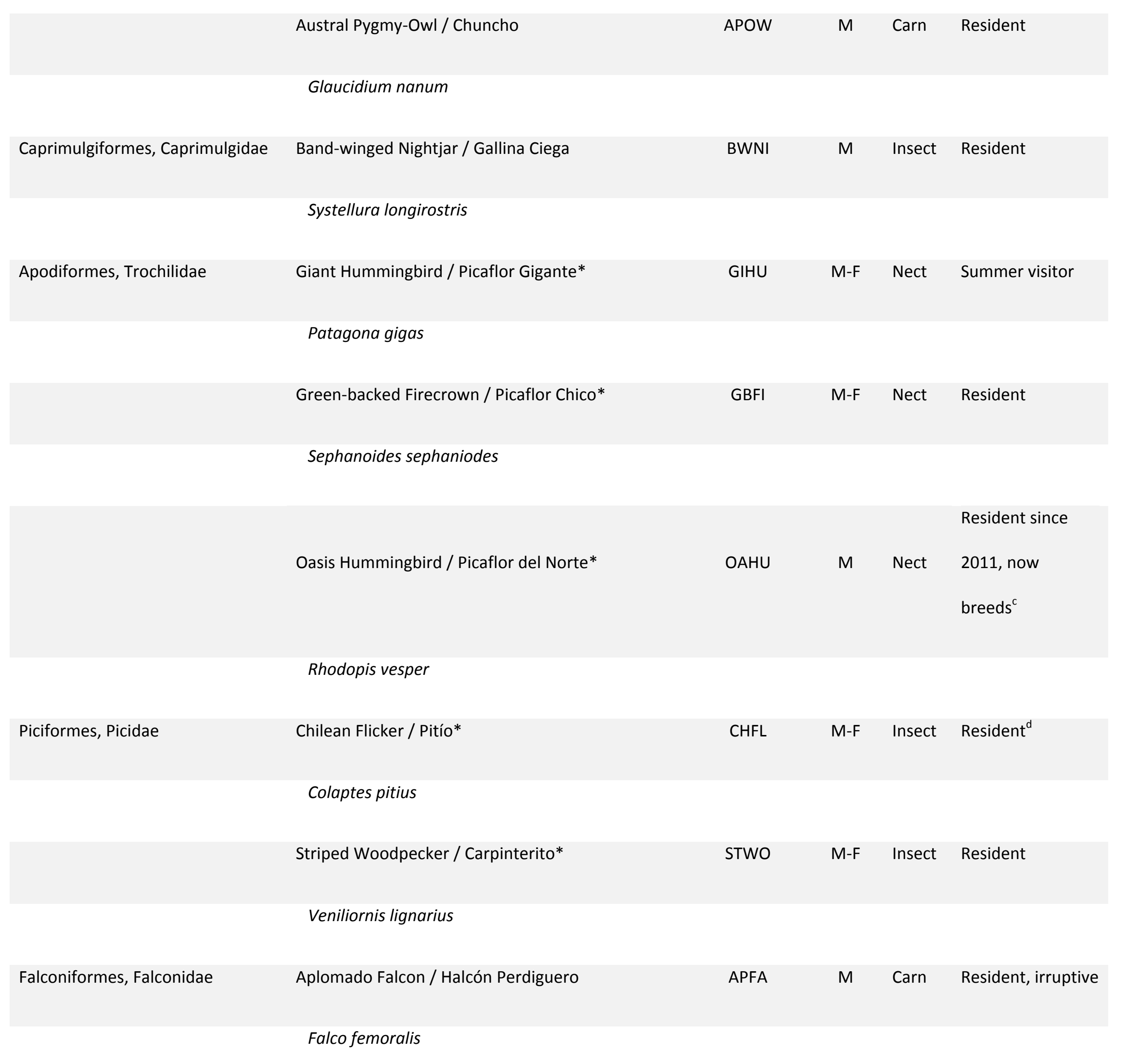




\begin{tabular}{|c|c|c|c|c|c|}
\hline & Peregrine Falcon / Halcón Peregrino & PEFA & M & Carn & Rare resident \\
\hline \multicolumn{6}{|c|}{ Falco peregrinus } \\
\hline & American Kestrel / Cernícalo & AMKE & M & Carn $^{1}$ & Resident \\
\hline \multicolumn{6}{|c|}{ Falco sparverius } \\
\hline & Chimango Caracara / Tiuque & $\mathrm{CHCA}$ & M & Carn $^{2}$ & Resident \\
\hline \multicolumn{6}{|c|}{ Milvago chimango } \\
\hline \multirow[t]{6}{*}{ Passeriformes, Rhinocryptidae } & Moustached Turca / Turca* & MOTU & M-F & Insect & Resident \\
\hline & \multicolumn{5}{|l|}{ Pteroptochos megapodius } \\
\hline & White-throated Tapaculo / Tapaculo* & WTTA & $M-F$ & Insect & Resident \\
\hline & \multicolumn{5}{|l|}{ Scelorchilus albicollis } \\
\hline & Dusky Tapaculo / Churrín del Norte* & DUTA & M-F & Insect & Resident \\
\hline & \multicolumn{5}{|l|}{ Scytalopus fuscus } \\
\hline \multirow[t]{5}{*}{ Passeriformes, Furnariidae } & Common Miner / Minero* & COMI & M & Insect $^{4}$ & Resident \\
\hline & \multicolumn{5}{|l|}{ Geositta cunicularia } \\
\hline & Rufous-banded Miner / Minero Cordillerano* & RBMI & M & Insect $^{4}$ & Occasional \\
\hline & \multicolumn{5}{|l|}{ Geositta rufipennis } \\
\hline & Creamy-rumped Miner /Minero Grande* & CRMI & M & Insect & Rare, spring \\
\hline
\end{tabular}


Geositta isabellina

\begin{tabular}{|c|c|c|c|c|c|}
\hline & Crag Chilia / Chiricoca & $\mathrm{CRCH}$ & M & Insect & Rare, spring \\
\hline \multicolumn{6}{|c|}{ Ochetorhynchus melanurus } \\
\hline & Scale-throated Earthcreeper / Bandurilla* & STEA & M & Insect & Winter visitor \\
\hline \multicolumn{6}{|c|}{ Upucerthia dumetaria } \\
\hline & Thorn-tailed Rayadito / Rayadito & TTRA & $\mathrm{F}$ & Insect & Resident \\
\hline \multicolumn{6}{|c|}{ Aphrastura spinicauda } \\
\hline & Plain-mantled Tit-Spinetail / Tijeral* & PMTS & $\mathrm{M}-\mathrm{F}$ & Insect & Resident \\
\hline \multicolumn{6}{|c|}{ Leptasthenura aegithaloides } \\
\hline & Dusky-tailed Canastero / Canastero* & DTCA & M & Insect & Resident \\
\hline \multicolumn{6}{|c|}{ Pseudasthenes humicola } \\
\hline \multirow[t]{5}{*}{ Passeriformes, Tyrannidae } & White-crested Elaenia / Fío-Fío* & WCEL & M-F & Insect & Summer visitor \\
\hline & \multicolumn{5}{|l|}{ Elaenia albiceps } \\
\hline & Tufted Tit-Tyrant / Cachudito* & TTTY & $M-F$ & Insect & Resident \\
\hline & \multicolumn{5}{|l|}{ Anairetes parulus } \\
\hline & Dark-faced Ground-Tyrant / Dormilona Tontita* & DFGT & M & Insect & Winter visitor \\
\hline
\end{tabular}




\begin{tabular}{|c|c|c|c|c|c|}
\hline \multirow[t]{2}{*}{ Passeriformes, Tyrannidae } & Great Shrike-Tyrant / Mero* & GSTY & M & Carn & Resident \\
\hline & \multicolumn{5}{|l|}{ Agriornis lividus } \\
\hline & Black-billed Shrike-Tyrant / Mero Gaucho & BBST & M & Insect & Rare, Spring \\
\hline \multicolumn{6}{|c|}{ Agriornis montanus } \\
\hline & Fire-eyed Diucon / Diucón* & FEDI & M-F & Insect & Resident \\
\hline \multicolumn{6}{|c|}{ Xolmis pyrope } \\
\hline & Patagonian Tyrant / Viudita* & PATY & M-F & Insect & $\begin{array}{l}\text { Winter visitor } \\
\text { (uncommon) }\end{array}$ \\
\hline & Colorhamphus parvirostris & & & & \\
\hline \multirow[t]{2}{*}{ Passeriformes, Cotingidae } & Rufous-tailed Plantcutter / Rara* & RTPL & M & Foliv & Transient \\
\hline & Phytotoma rara & & & & \\
\hline \multirow[t]{4}{*}{ Passeriformes, Hirundinidae } & $\begin{array}{l}\text { Blue-and-White Swallow / Golondrina de Dorso } \\
\text { Negro }\end{array}$ & BWSW & M & Insect & Occasional \\
\hline & \multicolumn{5}{|l|}{ Pygochelidon cyanoleuca } \\
\hline & Chilean Swallow / Golondrina Chilena* & CHSW & $M-F$ & Insect & Resident \\
\hline & Tachycineta meyeni & & & & \\
\hline Passeriformes, Troglodytidae & House Wren / Chercán* & SHWR & M-F & Insect & Resident \\
\hline
\end{tabular}




\begin{tabular}{|c|c|c|c|c|c|}
\hline \multirow[t]{2}{*}{ Passeriformes, Turdidae } & Austral Thrush / Zorzal* & AUTH & $\mathrm{M}-\mathrm{F}$ & Omn & Resident \\
\hline & \multicolumn{5}{|l|}{ Turdus falcklandii } \\
\hline \multirow[t]{2}{*}{ Passeriformes, Mimidae } & Chilean Mockingbird / Tenca* & CHMO & M & Omn & Resident \\
\hline & \multicolumn{5}{|l|}{ Mimus thenca } \\
\hline \multirow[t]{2}{*}{ Passeriformes, Motacillidae } & Correndera Pipit / Bailarín Chico & COPI & M & Insect $^{5}$ & Occasional \\
\hline & \multicolumn{5}{|l|}{ Anthus correndera } \\
\hline \multirow[t]{10}{*}{ Passeriformes, Thraupidae } & Grassland Yellow-Finch / Chirihue* & GYFI & M & Gran & Resident \\
\hline & \multicolumn{5}{|l|}{ Sicalis luteola } \\
\hline & Gray-hooded Sierra-Finch / Cometocino de Gay* & GHSF & $M-F$ & Gran & Resident \\
\hline & \multicolumn{5}{|l|}{ Phrygilus gayi } \\
\hline & Mourning Sierra-Finch / Yal* & MOSF & M & Gran & Resident \\
\hline & \multicolumn{5}{|l|}{ Phrygilus fruticeti } \\
\hline & Band-tailed Sierra-Finch / Platero* & BTSF & M & Gran & Resident \\
\hline & \multicolumn{5}{|l|}{ Phrygilus alaudinus } \\
\hline & Common Diuca-Finch / Diuca* & CDFI & M & Gran & Resident \\
\hline & \multicolumn{5}{|l|}{ Diuca diuca } \\
\hline Passeriformes, Emberizidae & Rufous-collared Sparrow / Chincol* & RCSP & $\mathrm{M}-\mathrm{F}$ & Gran & Resident \\
\hline
\end{tabular}


Zonotrichia capensis

Passeriformes, Icteridae

Austral Blackbird / Tordo*

AUBL

Resident

Curaeus curaeus

Shiny Cowbird / Mirlo*

SHBL

M Omn ${ }^{6}$ Occasional

Molothrus bonariensis

Long-tailed Meadowlark / Loica*

LTME M Omn Resident

Sturnella loyca

Passeriformes, Fringillidae

Black-chinned Siskin / Jilguero*

BCSI

M-F Gran Resident

Sporagra barbata

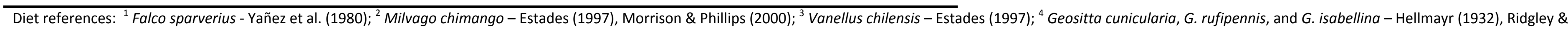
Tudor (1994); ${ }^{5}$ Anthus correndera - Tyler (2004); ${ }^{6}$ Molothrus bonariensis - Lowther \& Post (1999).

Status comments: ${ }^{\mathrm{a}}$ Common outside park but habitat inside park includes dense vegetation that is not favored by this species; ${ }^{\mathrm{b}}$ Common outside of park in agricultural regions; ${ }^{\mathrm{c}}$ Appears to be colonizing this region of Chile from more northern regions; ${ }^{\mathrm{d}}$ Common in forest fragments but only occasionally descends to matorral habitat. 